\title{
Advances in Synthesis of $\pi$-Extended Benzosilole Derivatives and Their Analogs
}

\author{
Tuan Thanh Dang ${ }^{1}$, Hue Minh Thi Nguyen ${ }^{2, *}$, Hien Nguyen ${ }^{2}$, Tran Ngoc Dung ${ }^{2}$, \\ Minh Tho Nguyen ${ }^{3,4}$ (1) and Wim Dehaen ${ }^{4, *}$ \\ 1 Department of Chemistry, Hanoi University of Science, Vietnam National University (VNU), \\ 19 Le Thanh Tong, Ha Noi 100000, Vietnam; dangthanhtuan@gmail.com \\ 2 Department of Chemistry and Center for Computational Science, Hanoi National University of Education, \\ 136 Xuan Thuy, Ha Noi 100000, Vietnam; hiennguyendhsphn@gmail.com (H.N.); \\ trandung171@gmail.com (T.N.D.) \\ 3 Institute for Computational Science and Technology (ICST), Ho Chi Minh City 700000, Vietnam \\ 4 Department of Chemistry, KU Leuven, Celestijnenlaan 200F, B-3001 Leuven, Belgium; \\ minh.nguyen@kuleuven.be \\ * Correspondence: hue.nguyen@hnue.edu.vn (H.M.T.N.); wim.dehaen@kuleuven.be (W.D.)
}

Received: 11 December 2019; Accepted: 8 January 2020; Published: 27 January 2020

\begin{abstract}
Benzosiloles and their $\pi$-extended derivatives are present in many important advanced materials due to their excellent physical properties. Especially, they have found many potential applications in the development of novel electronic materials such as OLEDs, semiconductors and solar cells. In this review, we have summarized several main approaches to construct (di)benzosilole derivatives and (benzo)siloles fused to aromatic five- and six-membered heterocycles.
\end{abstract}

Keywords: benzosiloles; fused benzosiloles; dibenzosilole; 9-silafluorenes; optoelectronic materials; silylation reactions

\section{Introduction}

Benzosiloles and their $\pi$-extended derivatives have attracted much attention because of their extraordinary properties in comparison with other well-known organic materials [1-17]. There are two types of $\pi$-extended benzosilole derivatives classified as ladder-type and spiro-type structures. Especially, dibenzosiloles (9-silafluorenes) possess unique photophysical and electronic properties such as high electron-transporting performances which could also be used in promising photovoltaic organic materials [1-17]. In fact, they are important motifs appearing as key building blocks in the structure of many kinds of novel light emitting materials, solar cells, semiconductors, electroluminescent materials [1-16]. Therefore, a lot of new synthetic methods for the formation of dibenzosilole derivatives have been widely developed [18-20]. Conventional methods for the synthesis of dibenzosilole derivatives are often based on the metal-halide exchange of dihalobiarenes, followed by cyclization with dichlorosilanes [21-24]. These reactions are often carried out under very low temperature conditions and/or for a long reaction time. On the other hand, this method may be disadvantageous in the synthesis of (di)benzosilole derivatives containing sensitive functional groups, which is often limiting further applications. In the light of recent advances in the field of transition metals catalysis, many new structures and applications of dibenzosilole analogs have been demonstrated, which contributed to the development of materials science $[18,19]$. In addition, the new cyclization reactions via a silyl radical process have given more efficient and sustainable approaches to benzosilole and dibenzosilole derivatives under mild conditions [20]. 


\section{Synthesis of $\pi$-Extended Benzosiloles}

\subsection{Conventional Metal-Halide Exchange Method}

In 1955, the first synthesis of 9,9-diphenylsilafluorene was reported by Gilman and Gorsich [25]. In this seminal publication, 2,2'-dilithiumdiphenyl was prepared by the lithium-bromide exchange of the corresponding dibromobiphenyl 1 with $n \mathrm{BuLi}$, and then reacted with one equivalent of diphenyldichlorosilane to afford to 9,9-diphenysilafluorene (2) in 49\% yield (Scheme 1, pathway A). Afterwards, there have been several modified procedures giving better yields of 9-silafluorene derivatives [21-24]. Due to excellent optoelectronic properties of 9-silafluorenes, the incorporation of 9-silafluorenes and related compounds in polymers have currently become an important topic in materials science [5]. Using this metal-halide exchange strategy, a series of monomers containing dibrominated 9-silafluorenes were successfully prepared [21-25]. In 2005, Homes, Cao groups disclosed the synthesis of dibrominated 9-silafluorene monomers 4, 9 which were used in the polymerization (Scheme 1 pathways B, C) [26,27]. In fact, poly(3,6-dibenzosiloles) 5 were prepared via Suzuki coupling of $\mathbf{3}$ and $\mathbf{4}$ in the presence of Pd catalyst in very good yields. Mw and Mn of polymer $\mathbf{5}$ was reported to be 23000 and 11000, respectively. In 2006, Huang et al. reported a general strategy to access from 7 via biphenyl derivative 8 the 2,7-dibromo-9-silafluorenes 9 which can be used as key building blocks in polymer chemistry [28]. Thus, these building blocks were employed in the synthesis of poly(2,7-dibenzosiloles) materials which have been described to be a new class of high energy gap light emitting polymers (Scheme 1) [28]. In order to explore novel optoelectronic properties, the utilization of 9-silafluorene derivatives as key building blocks in the synthesis of copolymers also gained much attentions (Scheme 1, pathway C) [10]. As a result of the combination of several well-known monomers, a series of novel copolymers $\mathbf{1 1}, \mathbf{1 4}$ containing the 9-silafluorene moiety were successfully prepared using Pd-catalyzed cross-coupling reactions [11,14].

A)

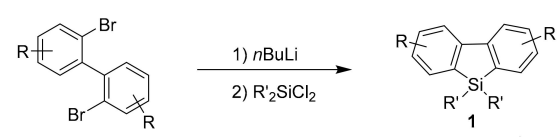

B)

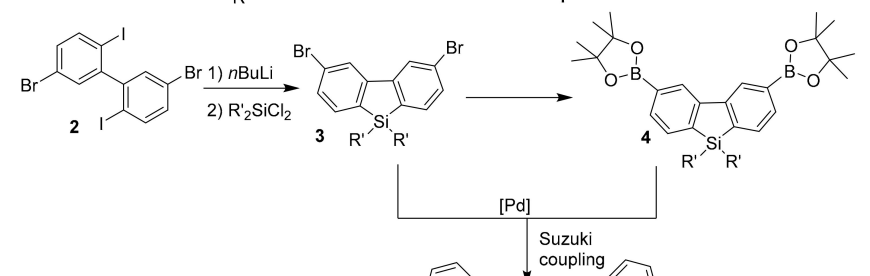

c)
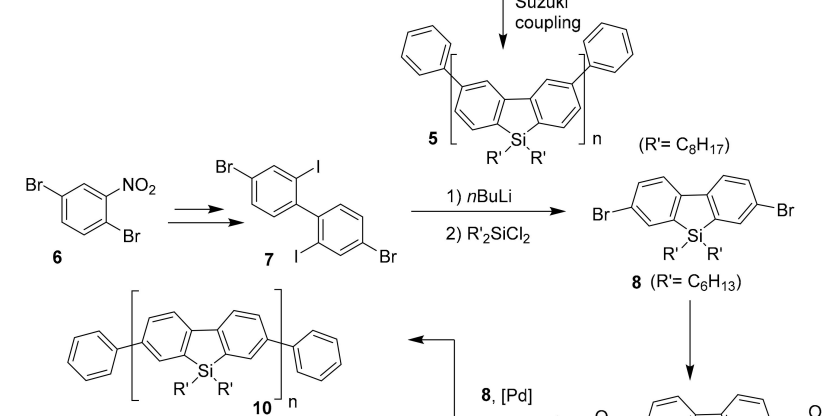

$8\left(\mathrm{R}^{\prime}=\mathrm{C}_{6} \mathrm{H}_{13}\right)$
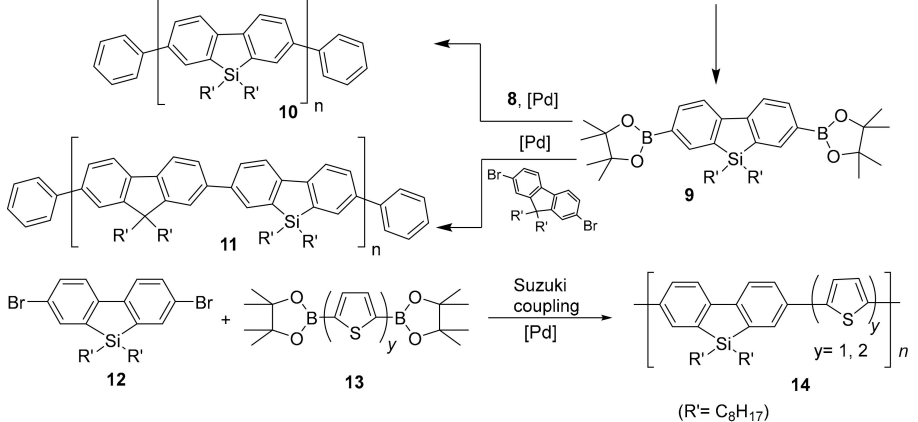

Scheme 1. Synthesis of dibenzosilole derivatives and dibenzosilole-containing polymers. 
Ashraf, Chen et al. reported an efficient synthesis of a novel fused coplanar chromophore, silaindacenodithiophene 16, by the tetra-lithiation of 2,5-bis(3-bromo-2-thienyl)-1,4-dibromobenzene 15 and then a subsequent addition of dichloro di- $n$-octylsilane as shown in Scheme 2 [29]. This key building block was employed (after conversion to the bistin derivative 17) in the synthesis of two silaindacenodithiophene (SiIDT) alternating copolymers 18 in field-effect transistors and photovoltaic devices. These polymers showed both very high ambipolar charge transport, with holes and electrons exhibiting mobilities and high solar cell efficiencies. At the same time, Jen and coworkers demonstrated the same approach in the synthesis of a silaindacenodithiophene monomer [30]. A similar Pd-catalysed synthesis of a new copolymer 19 which was used for the fabrication of solar cells by Stille coupling reaction has also been reported [31].

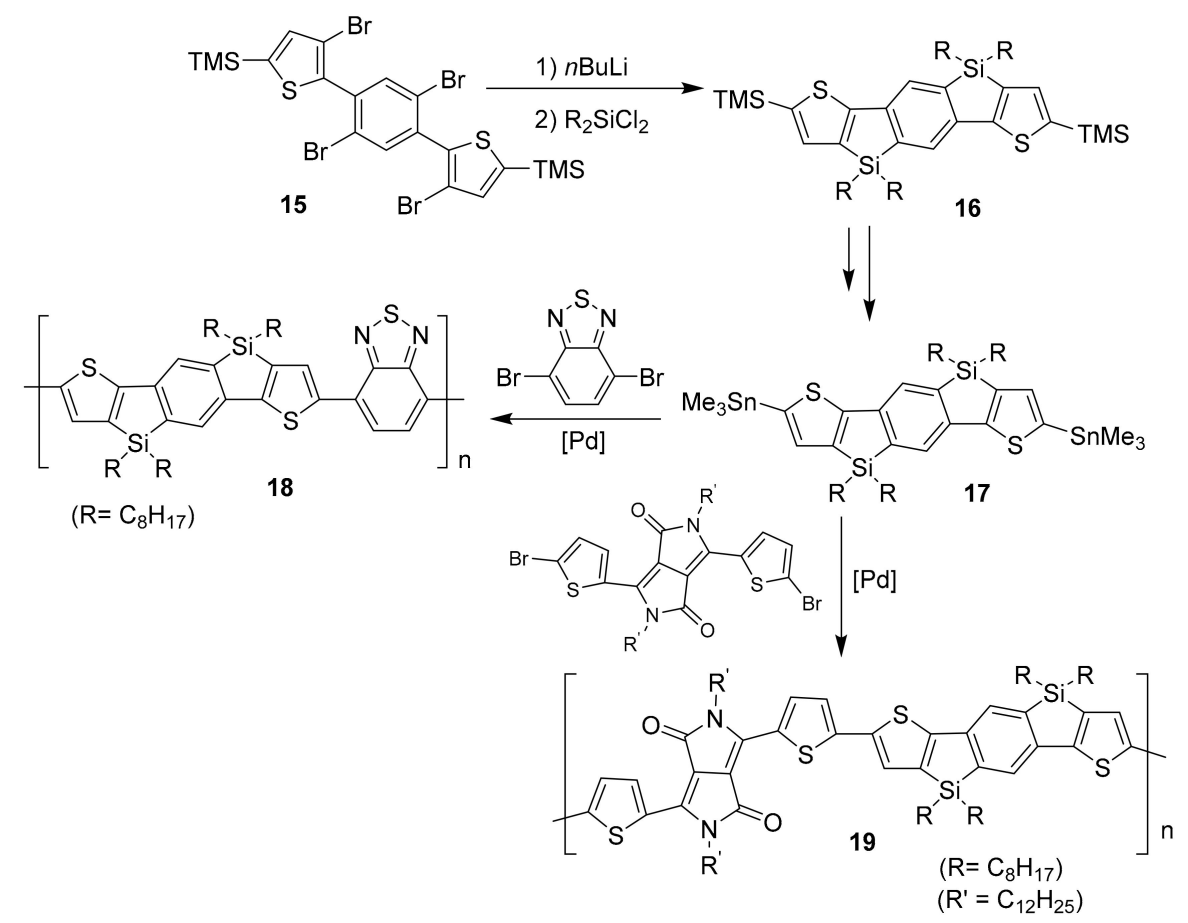

Scheme 2. Synthesis of $\pi$-extended dibenzosiloles and polymers containing dibenzosilole unit.

In 2017, Oestreich, Yamaguchi et al. reported a practical synthesis of heterocycle-fused benzosiloles 21 by two-fold metalation of benzo[b]thiophenes 20 followed by electrophilic substitutions with dichlorosilane derivatives (Scheme 3) [32]. The success of this procedure is based on the relatively high acidity of the $\mathrm{C}\left(\mathrm{sp}^{2}\right)-\mathrm{H}$ bond at the $\mathrm{C} 2$ position of the benzothiophene ring and the metal-halide exchange at the $\mathrm{C}\left(\mathrm{sp}^{2}\right)-\mathrm{Br}$ bond. A series of new benzothiophene-fused benzosiloles were successfully synthesized using this method.
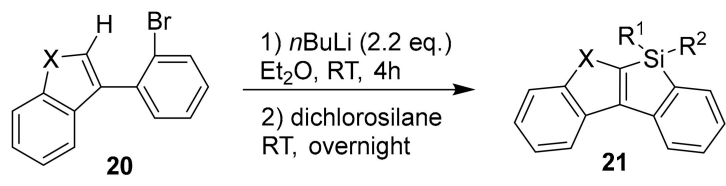

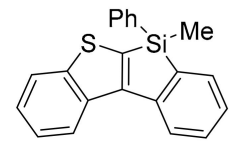

$84 \%$

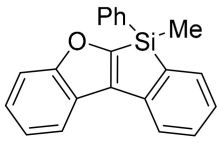

$72 \%$

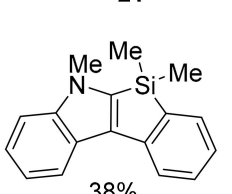

$38 \%$

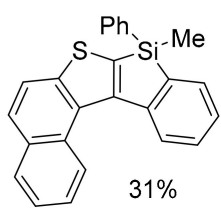

$31 \%$

Scheme 3. Synthesis of heterocycles-fused benzosiloles. 
Especially, Yamaguchi et al. described a new synthetic method for the synthesis of bis-silicon-bridged stilbene 23 by intramolecular reductive cyclization of bis(o-silyphenyl)acetylene 22 using lithium naphthalenide (LiNaph) followed by the treatment with iodine (Scheme 4) [33]. After lithiations with sec-BuLi, 2,7-diiodinated derivatives 25 were prepared by the treatment with molecular iodine. Starting from 2,7-diiodinated derivative 25 and 28, and building blocks 26 and 29, a series of polymers/copolymers 24, 27 and 30 were successfully synthesized by Pd-catalyzed cross-coupling polymerisations.
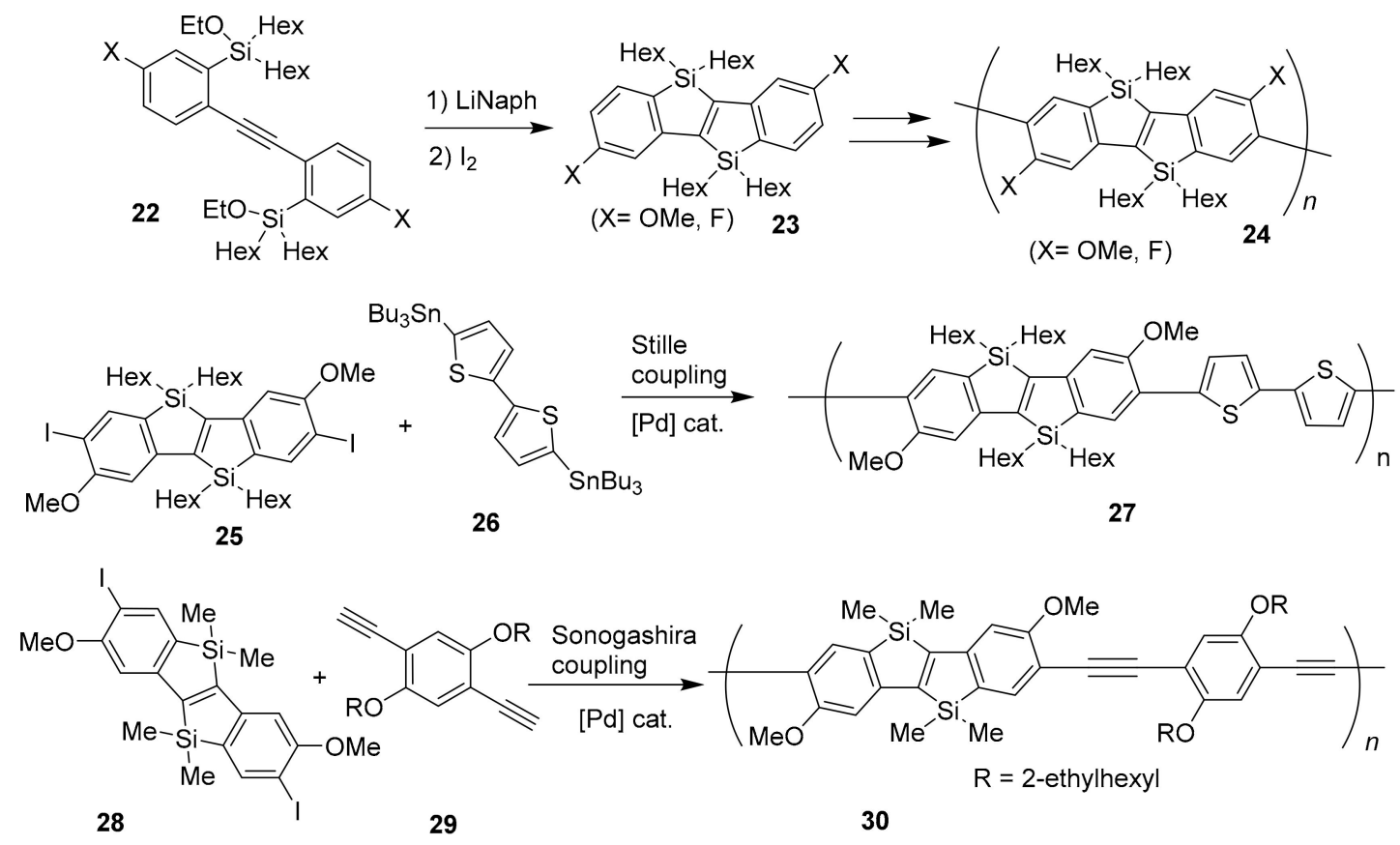

Scheme 4. Synthesis of bis-silicon-bridged stilbenes and polymers containing bis-silicon-bridged stilbene moiety.

In 1995, 9,9' -spiro-9-silabifluorene 33 was prepared from dibromobiphenyl 31 using a similar metal-halide exchange method. This molecule 33 showed high thermal stability (melting point is $227^{\circ} \mathrm{C}$ ) and could be used as the key building block in the structure of polymers, leading to an improvement in glass transition temperature $\left(T_{g}\right)$ and thermal stability (Scheme 5) [34]. Tian et al. developed a new copolymer 36 which combined 9,9'-spiro-9-silabifluorene and triphenylamine monomers via Suzuki cross coupling reaction of dibromo spirosilafluorene derivative $\mathbf{3 4}$ and triphenylamine diboronic acid 35 [35]. Several studies on molecular, thermal, optical and electroluminescent properties of 36 were carried out. The introduction of a spirosilafluorene as the key building block in this copolymer resulted in high thermal stability and good solubility in common organic solvents. This material showed a potential application as hole transport material in LED devices. Due to the extraordinary properties of $9,9^{\prime}$-spiro-9-silabifluorene, a series of novel derivatives of this molecule were synthesized by the introduction of different heteroatoms into the 9,9' -spiro-9-silabifluorene structure.

Since the preparation of heterocycle-fused benzosiloles and 9,9'-spiro-9-silabifluorenes became routine and practical, the introduction of other heteroatoms into the structure of these molecules is easy to be realized [36] starting from the appropriate building blocks such as 37 and 38 . Interestingly, heterocycle-fused 9,9' -spiro-9-silabifluorenes 39 and other analogs can react with one more equivalent of organolithium compounds to form pentacoordinate systems (hypervalent silicon-containing compounds) (Scheme 6) [37]. 

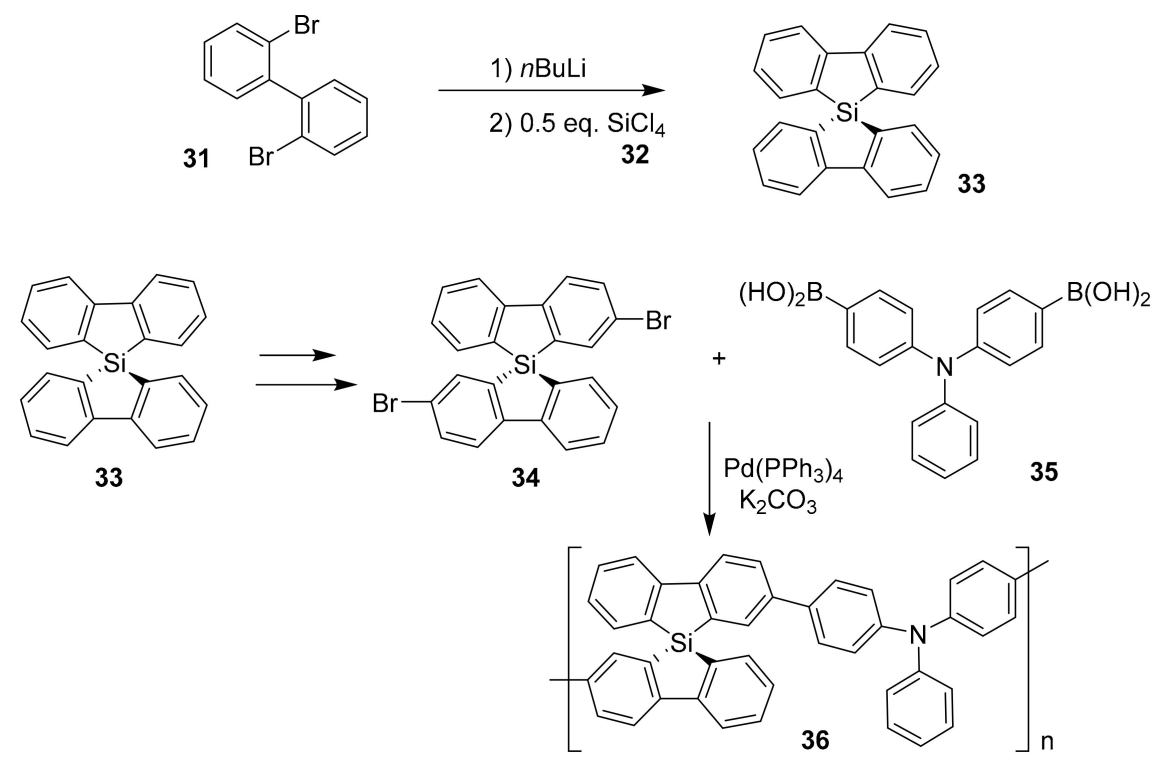

Scheme 5. Synthesis of 9,9'-spiro-9-silabifluorenes.<smiles>Brc1ccccc1-c1ncccc1Br</smiles>

37

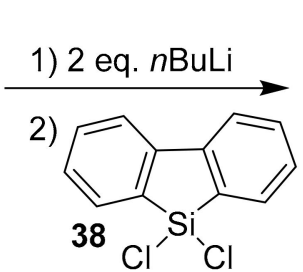<smiles>c1ccc(-c2ccccc2[Si]2(c3ccccc3)c3ccccc32)cc1</smiles>

39<smiles>[R][SiH]1c2ccccc2-c2sc3ccccc3c2[Si]1([R])c1ccccc1-c1ccccc1</smiles>

1) RLi

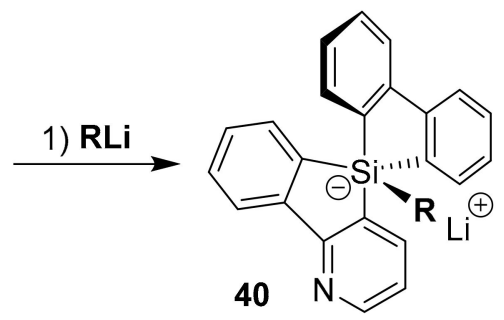

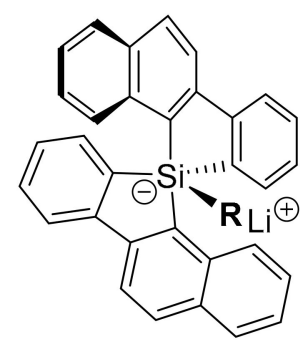

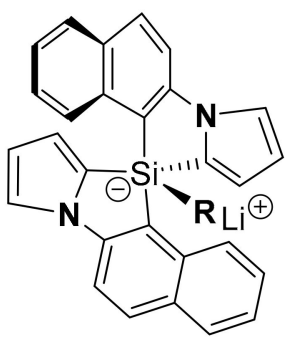

Scheme 6. Synthesis of hypervalent silicon compounds.

In 2007, Yamaguchi and coworkers reported a new cascade anionic double cyclization of (o-silylphenyl)(o-halophenyl)acetylenes $\mathbf{4 1}$ by an initial lithiation followed by adding chalcogen metals (S, Se) giving silicon and chalcogen-bridged stilbenes 45, 47, and 48 (Scheme 7) [7]. The success of this method to form $\mathrm{Si}$,S-bridged ladder phenylenevinylene structures relied on a new cascade anionic cyclization. Interestingly, the lithiation of $\mathbf{4 1}$ formed by the exchange with $t$-BuLi followed by adding elemental sulfur gave a thiolate anion $\mathbf{4 2}$, which further cyclized via a 5-endo-dig process, followed by a nucleophilic substitution at the silicon center to afford the doubly-cyclized Si,S-bridged stilbene 43 . Based on the success of this cyclization, a series of diacetylenic starting materials 44 and 46 have been successfully used to prepare several ladder distyrylbenzenes 45,47 , and 48 in moderate yields. Along with these syntheses, several interesting results in molecular packing studies and physical properties such as high intensity fluorescence pointed towards their potential applications in organic electronic devices [7]. 

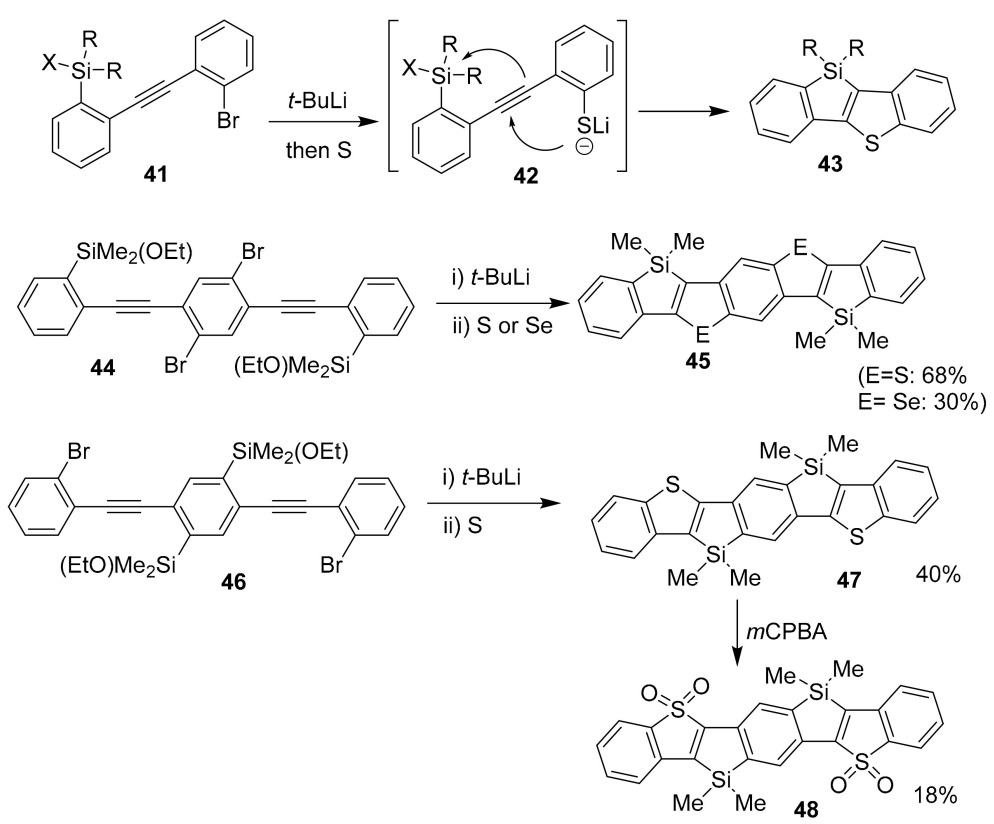

Scheme 7. Synthesis of ladder molecules.

\subsection{Metal-Catalyzed [2+2+2] Cycloadditions}

Recent development of modern synthetic methods using transition metal catalysts have given efficient pathways to form large $\pi$-conjugated polycyclic fused dibenzosilole structures. Thus, there have been many synthetic methods developed for the synthesis of 9-silafluorene and derivatives. Transition metal-catalyzed [ $2+2+2]$ cycloaddition reaction of alkynes to form a benzene ring has been successfully applied in the synthesis of 9-silafluorene and its $\pi$-extended derivatives [38]. In 2007, Murakami and coworkers reported the first Ir-catalyzed synthesis of 9 -silafluorene derivatives $\mathbf{5 1}$ by the [2+2+2] cycloaddition of silicon-bridged 1,6-diynes 49 with alkynes 50 (Scheme 8) [38]. Ladder-type $\pi$-extended systems have attracted much attention due to effective conjugation by these rigid coplanar structures. In this study, $\pi$-extended 9-silafluorene structures $\mathbf{5 4}, \mathbf{5 6}, \mathbf{5 8}$ were efficiently synthesized by the $[2+2+2]$ cycloaddition of tetraynes $\mathbf{5 2}, 55$ and 57 , respectively with alkyne 53 (Scheme 9). For instance, this method was efficiently applied to the synthesis of a 9,9'-spiro-9-silabifluorene derivative 58 in $85 \%$ isolated yield. Some studies on photophysical and thermal properties of these molecules were performed. Interestingly, molecule 58 exhibited an exceptionally high fluorescent efficiency (91\%) [38].

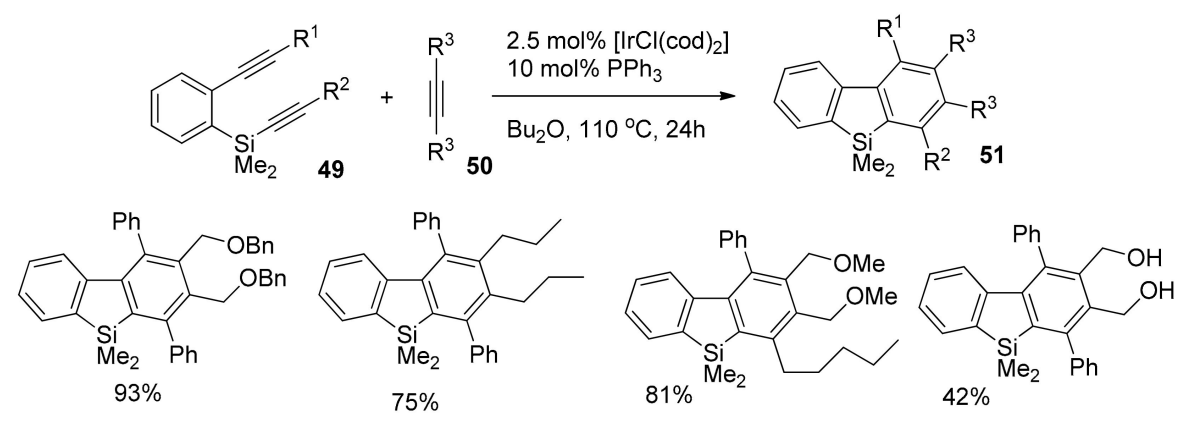

Scheme 8. Synthesis of 9-silafluorenes via Ir-catalyzed [2+2+2] cycloaddition. 

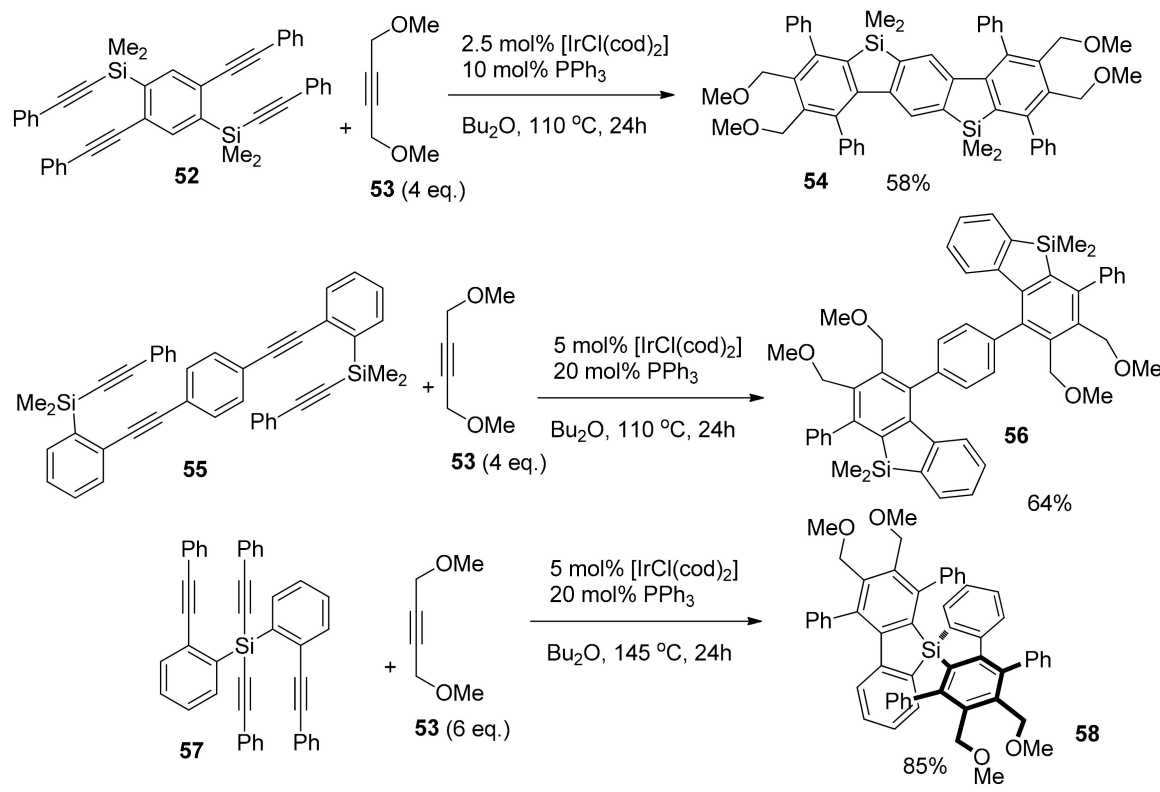

Scheme 9. Synthesis of $\pi$ extended 9-silafluorenes.

This approach has become one of the most important methods to construct ladder-type $\pi$-extended systems containing a 9-silafluorene moiety. Inspired by this pioneering work, the Shibata group has developed an enantioselective synthesis of chiral silahelicenes using Ir-catalyzed [2+2+2] cycloaddition in the key step (Scheme 10) [39]. In order to get a high yield and enantiomeric excess (e.e.) for this reaction, several chiral bidentate ligands were screened, and $(S, S)$-EtFerroTANE ligand in combination with $\left[\operatorname{Ir}(\operatorname{cod}) \mathrm{Cl}_{2}\right.$ catalyst gave a cyclized product 61 (up to $51 \%$ yield and $94 \%$ e.e.) starting from tetrayne $\mathbf{5 9}$ and diyne $\mathbf{6 0}$. The subsequent stereospecific intramolecular transformation of chiral triyne $\mathbf{6 1}$ did not afford the desired product in satisfying yield while using Ir catalysts. Surprisingly, tandem $\mathrm{Ni}(\mathrm{cod})_{2} / \mathrm{PPh}_{3}$ catalysed cyclizations of chiral triyne intermediates 61 provided target silahelicene 62 in up to $97 \%$ yield and $92 \%$ e.e. without losing enantiomeric excess.

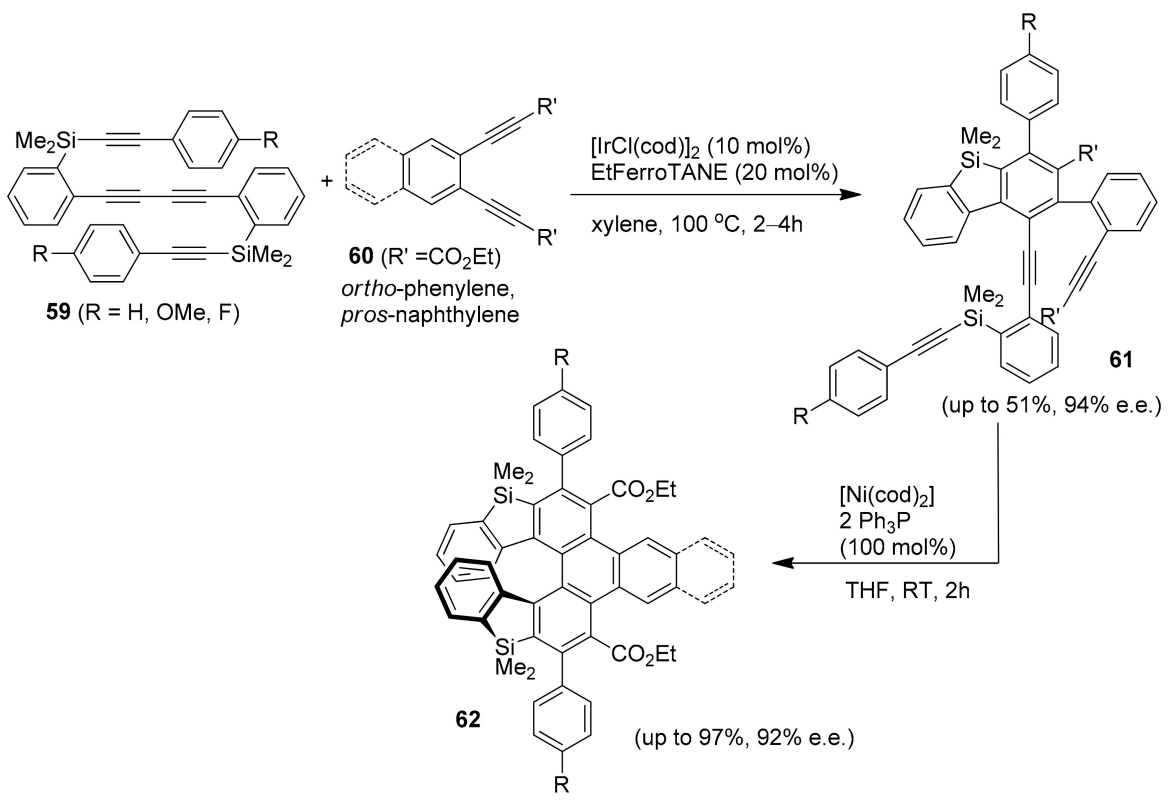

Scheme 10. Synthesis of helicene containing 9-silafluorene moiety.

Recently, Shibata et al. have developed the first example of sequential hexadehydro-Diels-Alder (HDDA) and tetradehydro-Diels-Alder (TDDA) reactions using silicon-tethered tetraynes 63 containing 
a 1,3-diyne moiety via benzosilole-fused benzynes 64 (Scheme 11) [40]. Notably, the silicon-containing polycyclic aromatic system obtained acted as a diene and underwent [4+2] cycloaddition with active alkynes. Along with the main product 65 , a side product 68 was isolated and its structure was confirmed by X-ray single crystallography. Remarkably, this undesired side product, a novel eight-membered ring system, was formed via a new thermal $[2+2+2+2]$ cycloaddition of alkynes 67 formed from 66 by cyclotrimerization (Scheme 12). After several optimizations, the yield of 68 was increased to $49 \%$ when the reaction was carried out under more concentrated conditions in chlorobenzene solvent.
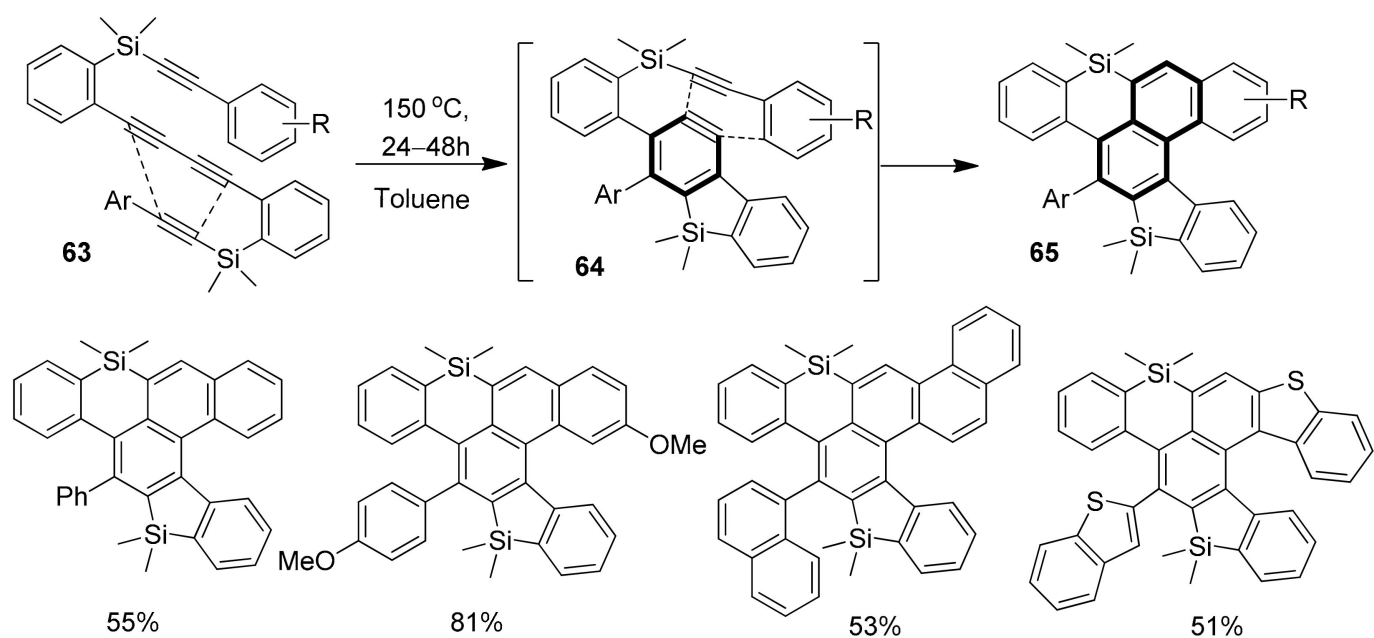

Scheme 11. Synthesis of 9-silafluorenes via cycloaddition.
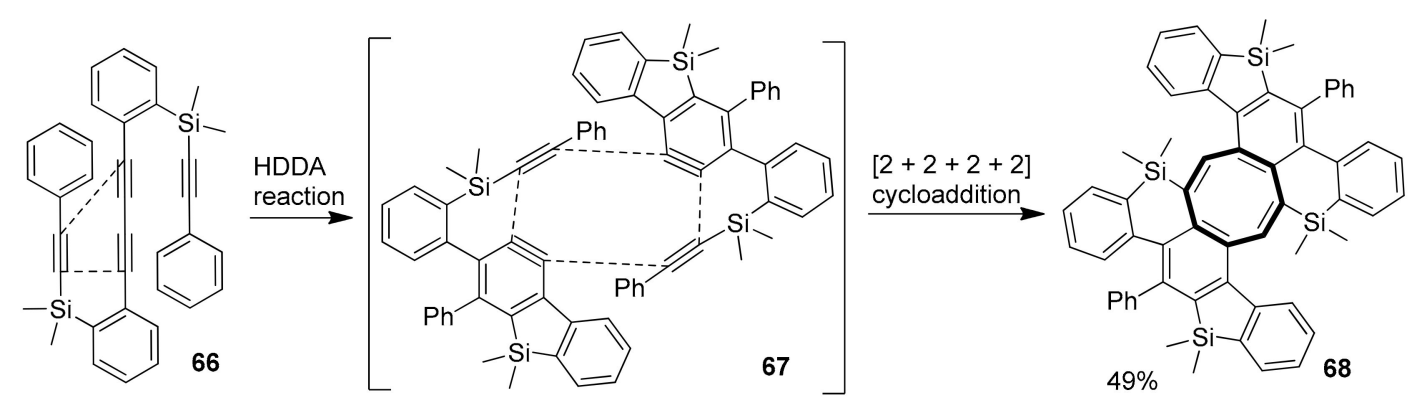

Scheme 12. Synthesis of 9-silafluorenes via [2+2+2+2] cycloaddition.

\subsection{Transition Metal Catalyzed C-Si Coupling via Cleavage of a C(sp $\left.{ }^{3}\right)$-Si Bond}

The introduction of an aryl group or a heteroatom into the dibenzosilole ring is instrumental in modifying, and possibly improving the physical properties of the parent (di)benzosiloles. In order to prepare new fused benzosiloles and explore interesting photophysical properties, many synthetic approaches to these motifs have been developed. Among them, recent synthetic methods using transition metals as catalysts in the activation of the Si-C bond have been reported [41]. Especially, Chatani et al. disclosed straightforward Rh-catalyzed $\mathrm{Si}-\mathrm{C}$ bond activations by transmetalation between arylboronic acids or esters and alkynes. Benzosilole derivatives were prepared in very good yields (up to 98\%) [41]. Inspired by this research, He and coworkers developed a new tandem cyclization/Si-C activation process to access heterocycle-fused dibenzosiloles under mild conditions (Scheme 13) [42]. The authors rationalized that the initial intramolecular cyclization of the triflated aniline 69 would form a Rh intermediate 70, and a subsequent $\mathrm{Si}-\mathrm{C}$ bond activation would give a cyclized indole-fused benzosilole product 71. An uncyclized indole side product 72 was also isolated in lower yield. The choice for the trifluoromethanesulfonyl group plays an important role in the success of the cyclization reaction. The reaction was also applied to phenols, affording benzofuro derivatives $71(X=O)$ albeit in a lower yield. 

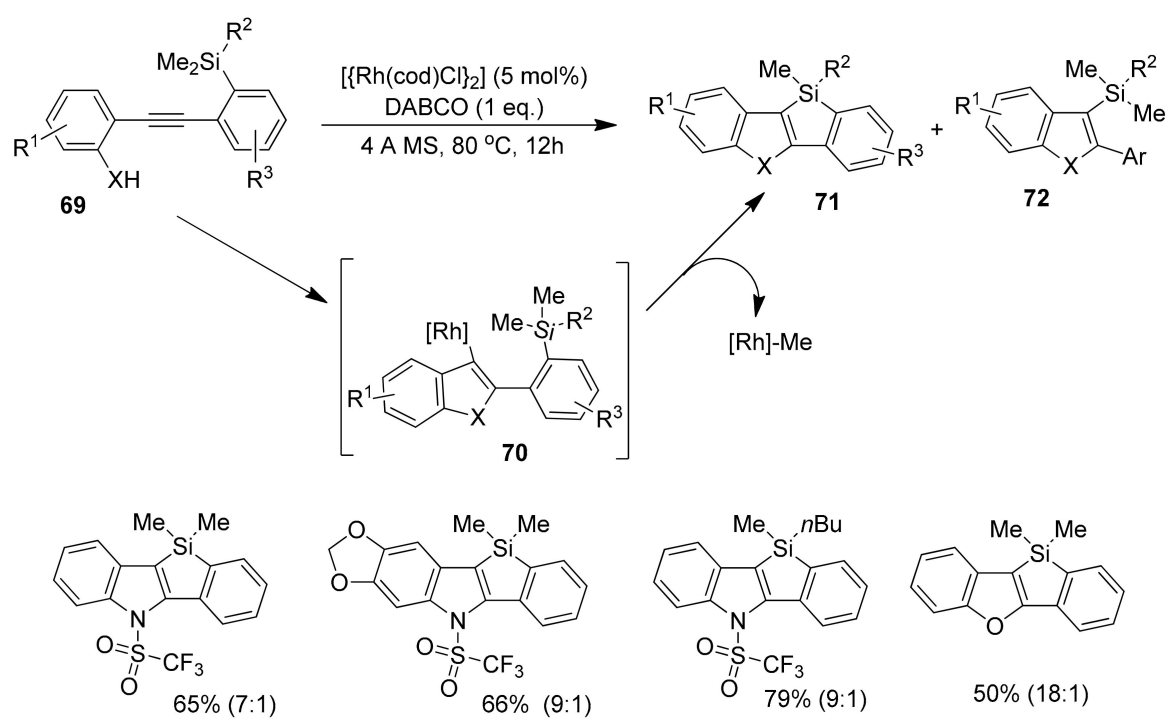

Scheme 13. Rh-catalyzed synthesis of heterocycles-fused benzosiloles.

In another approach, $\mathrm{Xi}$ et al. demonstrated an efficient Pd-catalyzed synthesis of 9-silafluorenes 74 and benzosilolo[2,3-b]indoles 76 via cleavage of a $\mathrm{C}\left(\mathrm{sp}^{3}\right)-\mathrm{Si}$ bond (of starting materials 73 and 75) and subsequent intramolecular $\mathrm{C}\left(\mathrm{sp}^{2}\right)-\mathrm{Si}$ coupling cyclization (Schemes 14 and 15) [43]. In this transformation, 4-nitrobenzaldehyde $\mathbf{8 0}$ plays a key role in promoting the efficiency of the catalytic cycle affording cyclized products in high yields (Scheme 15).
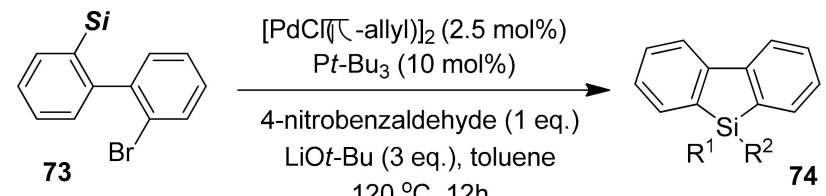

\begin{tabular}{cll|}
\hline $\boldsymbol{S i}=\mathrm{SiMe}_{3}$ & $\mathrm{R}^{1}=\mathrm{R}^{2}=\mathrm{Me}$ & $82 \%$ \\
$\mathrm{SiMe}_{2} \mathrm{Et}$ & $\mathrm{R}^{1}=\mathrm{Me}, \mathrm{R}^{2}=\mathrm{Et}$ & $66 \%$ \\
$\mathrm{SiMe}_{2}(i-\mathrm{Pr})$ & $\mathrm{R}^{1}=\mathrm{Me}, \mathrm{R}^{2}=i-\mathrm{Pr}$ & $73 \%$ \\
$\mathrm{SiMe}_{2} \mathrm{Ph}$ & $\mathrm{R}^{1}=\mathrm{Me}, \mathrm{R}^{2}=\mathrm{Ph}$ & $70 \%$ \\
$\mathrm{SiEt}_{3}$ & $\mathrm{R}^{1}=\mathrm{R}^{2}=\mathrm{Et}$ & $30 \%$ \\
\hline
\end{tabular}

Scheme 14. Pd-catalyzed synthesis of 9-silafluorenes.

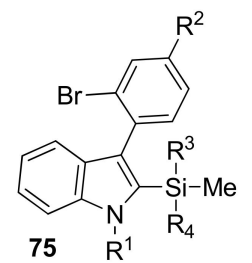

$$
\begin{gathered}
\underset{[\mathrm{PdCl}(\mathrm{T}-\text { allyl })]_{2}(2.5 \mathrm{~mol} \%)}{\mathrm{Pt}-\mathrm{Bu}_{3}(10 \mathrm{~mol} \%)} \\
\stackrel{\text { 4-nitrobenzaldehyde (1 eq. })}{\text { LiOt-Bu }(3 \text { eq. }) \text {, toluene }} \\
120^{\circ} \mathrm{C}, 12 \mathrm{~h}
\end{gathered}
$$
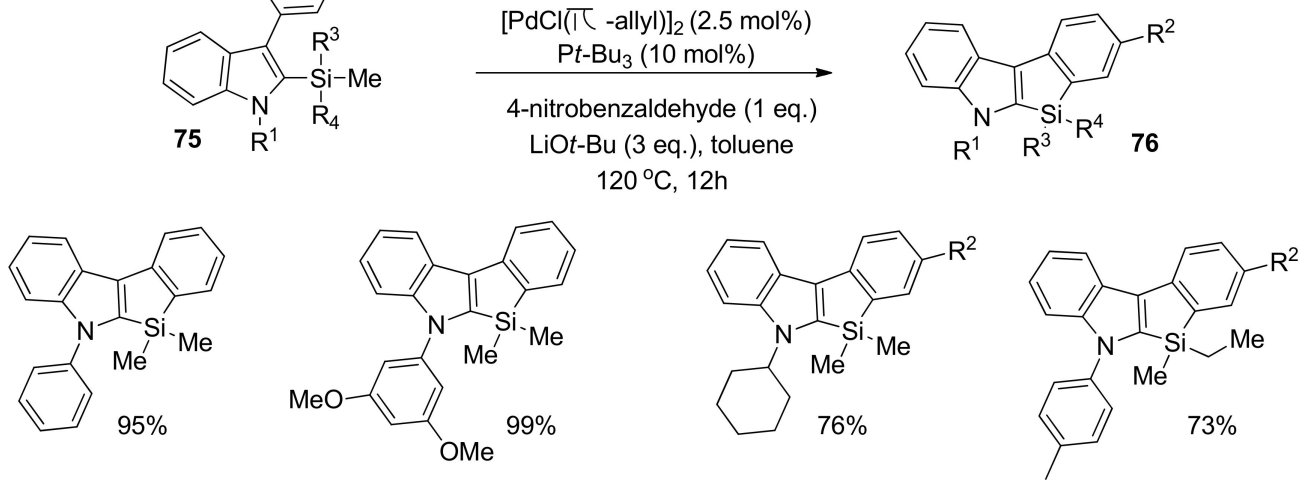

Scheme 15. Pd-catalyzed synthesis of heterocycles-fused benzosiloles. 
In order to understand the reaction mechanism, several control experiments were carried out. In the absence of 4-nitrobenzaldehyde $80, \mathrm{MeBr}$ was detected by GC-MS analysis. In the presence of 4-nitrobenzaldehyde 80, the reaction did not produce $\mathrm{MeBr}$. In fact, the formation of $\mathrm{CH}_{4} \mathrm{Was}_{\text {also }}$ confirmed by GC-MS measurement. Significantly, $t$-butyl-4-nitrobenzoate 82 was isolated in 55\% yield. Based on these interesting results, a plausible catalytic mechanism for the selective cleavage of $\mathrm{CH}_{3}-\mathrm{Si}$ bond of $\mathbf{7 7}$ and subsequent intramolecular C-Si coupling cyclization, involving intermediate $\mathbf{7 8}$ and leading to dibenzosilole 79, was proposed (Scheme 16) [43].

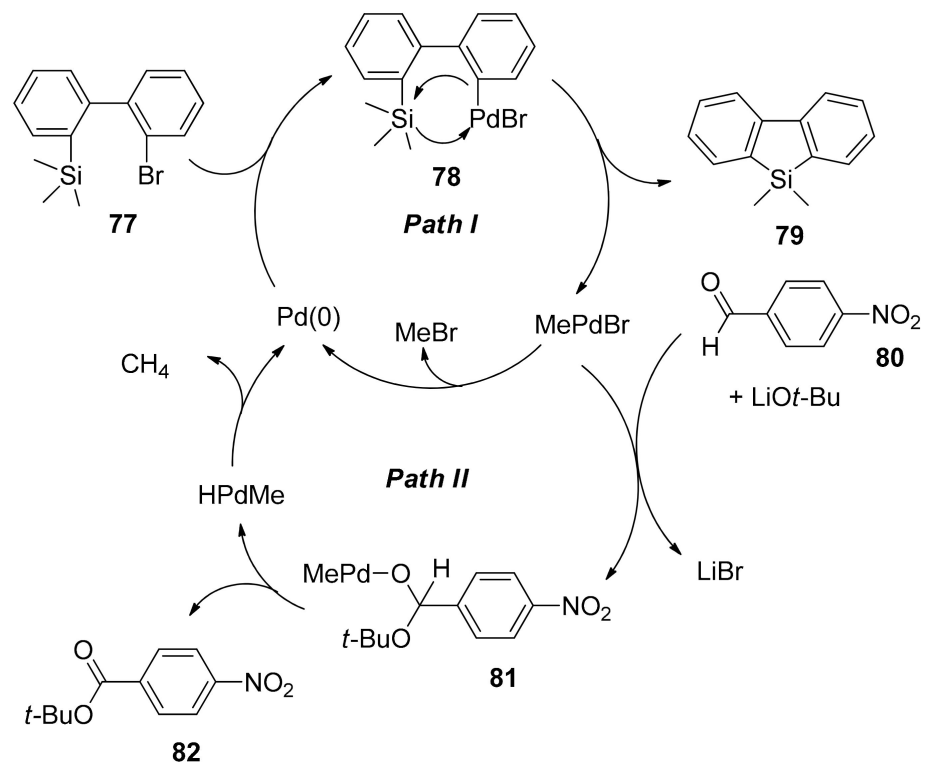

Scheme 16. Plausible mechanism for Pd-catalyzed synthesis of 9-silafluorene.

\subsection{Metal-Catalyzed C-H Activations}

Transition metal catalyzed arylation of arenes with aryl halides via a C-H activation method has become a very important tool for the construction of aryl-aryl bond formations [21-24]. Especially, direct Pd-catalyzed intramolecular arylation using silicon-tethering biaryl substrates 83 gave a straightforward pathway to construct heterocycle-fused benzosiloles $\mathbf{8 4}$ in very good yields (up to 95\%) (Scheme 17) [44,45]. It is important for these Pd-catalyzed intramolecular cyclizations to install bulky substituents on the silicon atom and to employ $\mathrm{Et}_{2} \mathrm{NH}$ base. Furthermore, Shimizu and coworkers realized that these silicon-bridged biaryl molecules showed promising solid state fluorescence. Target compounds exhibiting high solid state luminescent efficiently are currently an important subject of research in the development of OLEDs. Surprisingly, these compounds, when dispersed in a poly(methyl methacrylate) (PMMA) film, showed an intense blue emission with high quantum yield (up to 1.0).

Based on the success of this research, Shimizu et al. tried to prepare new derivatives of this molecule 84 in order to explore their extraordinary physical properties [46]. Instead of using $\mathrm{PCy}_{3}$ as a monodentate ligand, a bidentate ligand (dppe) was used in the combination with $\mathrm{Pd}(\mathrm{OAc})_{2}$ catalyst (Scheme 18). Surprisingly, this led to the observation of a new Pd-catalyzed domino process which consisted of an initial intramolecular coupling of $\mathbf{8 5}$ followed by a novel rearrangement of the C-Si bond to form indole-fused benzosiloles 86 in moderate to very good yields. Similar to the previous report, all of the prepared compounds showed excellent blue fluorescence with high quantum yields in the solid state. 

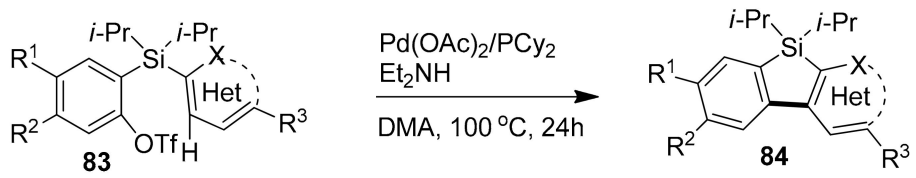

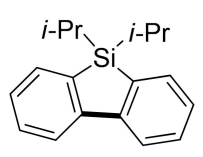

$92 \%$<smiles>CCC[Si]1(C(C)C)c2ccccc2-c2sccc21</smiles>

$94 \%$

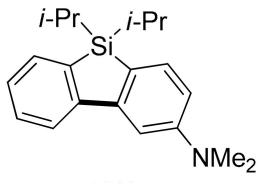

$90 \%$

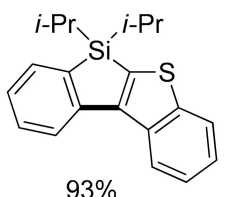<smiles>CCC[Si]1(C(C)C)c2ccccc2-c2cc(C(F)(F)F)ccc21</smiles>

$88 \%$<smiles>CCCC[Si](CCC)(C(=P)P)c1ccc(C#N)cc1-c1ccc(OC)cc1</smiles>

$93 \%$

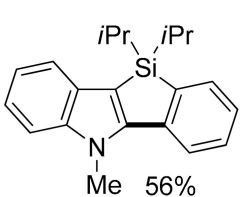

Scheme 17. Pd-catalyzed synthesis of 9-silafluorenes and heterocycles-fused benzosiloles.<smiles></smiles>

85

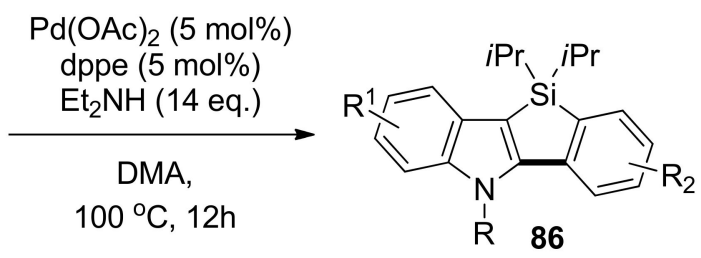<smiles>CC(C)[Si]1(C(C)C)c2ccccc2-c2c1n(C(C)(C)C)c1ccccc21</smiles><smiles>Cc1ccc(S(=O)(=O)n2c3c(c4ccccc42)[Si](C(C)C)(C(C)C)c2ccccc2-3)cc1</smiles><smiles>CC(C)[Si]1(C(C)C)c2cc(C#N)ccc2-c2c1n(C)c1ccccc21</smiles><smiles>COc1ccc2c(c1)c1c(n2C)[Si](C(C)C)(C(C)C)c2ccccc2-1</smiles><smiles>CC(C)[Si]1(C(C)C)c2ccc(F)cc2-c2c1n(C)c1ccccc21</smiles><smiles>CC(C)[Si]1(C(C)C)c2ccccc2-c2c1ccn2-c1ccccc1</smiles><smiles>Cc1ccc(S(=O)(=O)n2ccc3c2[Si](C(C)C)(C(C)C)c2ccccc2-3)cc1</smiles><smiles>CC(C)[Si]1(C(C)C)c2cccc3cccc(c23)-c2c1n(C)c1ccccc21</smiles>

Scheme 18. Pd-catalyzed synthesis of rearranged heterocycles-fused benzosiloles.

A plausible mechanism for the formation of indole-fused benzosiloles was proposed in the Scheme 19 [46]. In general, the first oxidative addition (OA) of Pd catalyst to starting material 87 occurred to afford arylpalladium 88 which could undergo intramolecular electrophilic substitution (ES) to give the palladacycle intermediate 89 (route a), followed by a 1,2-migration step leading to cationic palladacycle $\mathbf{9 0}$. In another pathway, cationic palladacycle 90 could be formed via the direct palladation at the 2-position (route b). During the course of this reaction, a byproduct 94 was often isolated which is valuable evidence for the more plausible route a. Subsequently, 1,2-Si-migration process of cationic palladacycle intermediate $\mathbf{9 1}$ followed by deprotonation by an amine and then finally reductive elimination (RE) provided the desired product 93 and regenerated the $\operatorname{Pd}(0)$ catalyst for the next catalytic cycle. The formation of the byproduct 94 could be explained by the presence of an EWG in the substrates which may destabilize cationic intermediate 89 and retard the Pd migration step. 


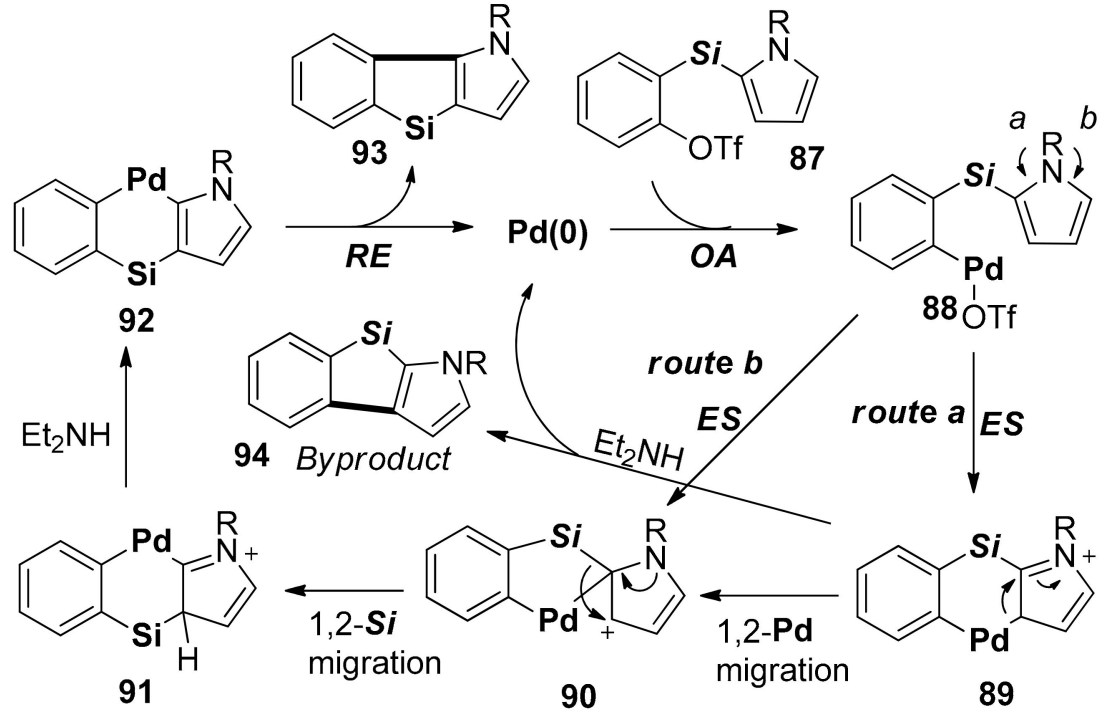

Scheme 19. Possible mechanism for Pd-catalyzed synthesis of heterocycles-fused benzosiloles.

\section{5. $\mathrm{C}-\mathrm{H}$ Silylations}

\subsubsection{Transition Metal-Catalyzed C-H Silylations}

Due to the importance of silicon-containing molecules with potential applications in material science and medicinal chemistry, the formation of a C-Si bond of benzosilole 96 by direct $\mathrm{C}-\mathrm{H}$ activation of precursor 95 currently is an interesting topic in modern organic synthesis $[18,19]$. This approach could give a straightforward approach to value-added molecules offering a single step reaction and atom economy in comparison to classic processes. According to the proposed concepts by Cheng and Hartwig [19], this method could be divided into three categories: (i) directing-group-assisted intermolecular $\mathrm{C}-\mathrm{H}$ silylation, (ii) undirected intermolecular $\mathrm{C}-\mathrm{H}$ silylation, and (iii) intramolecular C-H silylation (Scheme 20).

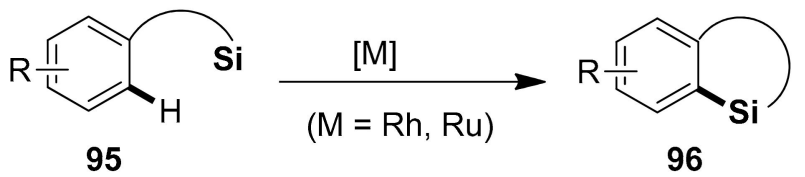

Scheme 20. General strategy for transition metal-catalyzed synthesis of fused benzosiloles.

Among these concepts, the process via transition metal catalyzed intramolecular $\mathrm{C}-\mathrm{H}$ arylation is the easiest to be carried out. The Takai group reported the first Rh-catalyzed synthesis of 9-silafluorenes 98 using the cleavage of $\mathrm{Si}-\mathrm{H}$ and $\mathrm{C}-\mathrm{H}$ bonds of 97 [47]. In this process, a new $\mathrm{Si}-\mathrm{C}$ bond was formed by the activation of both $\mathrm{Si}-\mathrm{H}$ and $\mathrm{C}-\mathrm{H}$ via dehydrogenation. Notably, only low catalyst loading $\left(0.5 \mathrm{~mol} \%\right.$ of $\left.\mathrm{Rh}\left(\mathrm{PPh}_{3}\right)_{3} \mathrm{Cl}\right)$ and short reaction times $(15 \mathrm{~min})$ were required to give high yields of silafluorene derivatives (up to $96 \%$ ). This method was demonstrated to be very efficient for the synthesis of ladder-type bis-silicon-bridged $p$-terphenyl 100 using a double cyclisation starting from 99 (Scheme 21).

Takai and coworkers proposed a possible mechanism (Scheme 22) for the Rh-catalyzed synthesis of 9-silafluorenes 105 which may occur through some steps as following: (i) oxidative addition of hydrosilane group to $\mathrm{Rh}$ catalyst via $\mathrm{Si}-\mathrm{H}$ bond activation of 101; (ii) subsequently oxidative addition of aromatic $\mathrm{C}-\mathrm{H}$ bond to $\mathrm{Rh}$ center of $\mathbf{1 0 2}$ via $\mathrm{C}-\mathrm{H}$ activation (route a or route b); (iii) reductive elimination of either 103 or 104 to provide 9-silafluorene products 105 and regenerate the Rh catalyst for the next catalytic cycle [47]. Then, a simple study involving deuterium labelling experiments was 
performed to understand the rate-determining step for the formation of 9-silafluorenes. This result confirmed that the $\mathrm{C}-\mathrm{H}$ bond activation of the phenyl group is the rate-determining step.

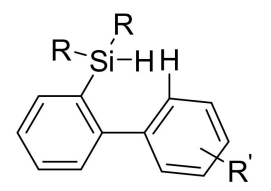

97

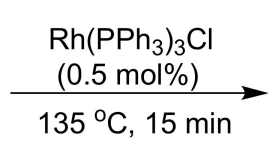

Dioxane

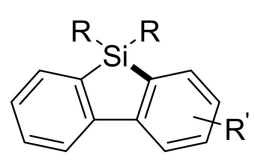

98<smiles>CC[Si]1(CC)c2ccccc2-c2ccccc21</smiles>

$94 \%$<smiles>C[Si]1(C)c2ccccc2-c2cc(F)ccc21</smiles>

$95 \%$<smiles>Cc1ccc2c(c1)-c1ccccc1[Si]2(C)C</smiles><smiles>CC(C)(C)c1ccc2c(c1)-c1ccccc1[Si]2(C)C</smiles><smiles>COc1cccc2c1[Si](C)(C)c1ccccc1-2</smiles>
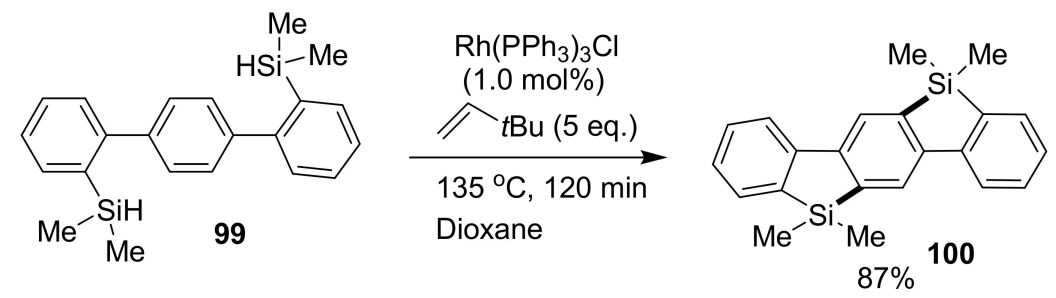

Scheme 21. Synthesis of benzosilole derivatives by Rh-catalyzed C-H silylation.

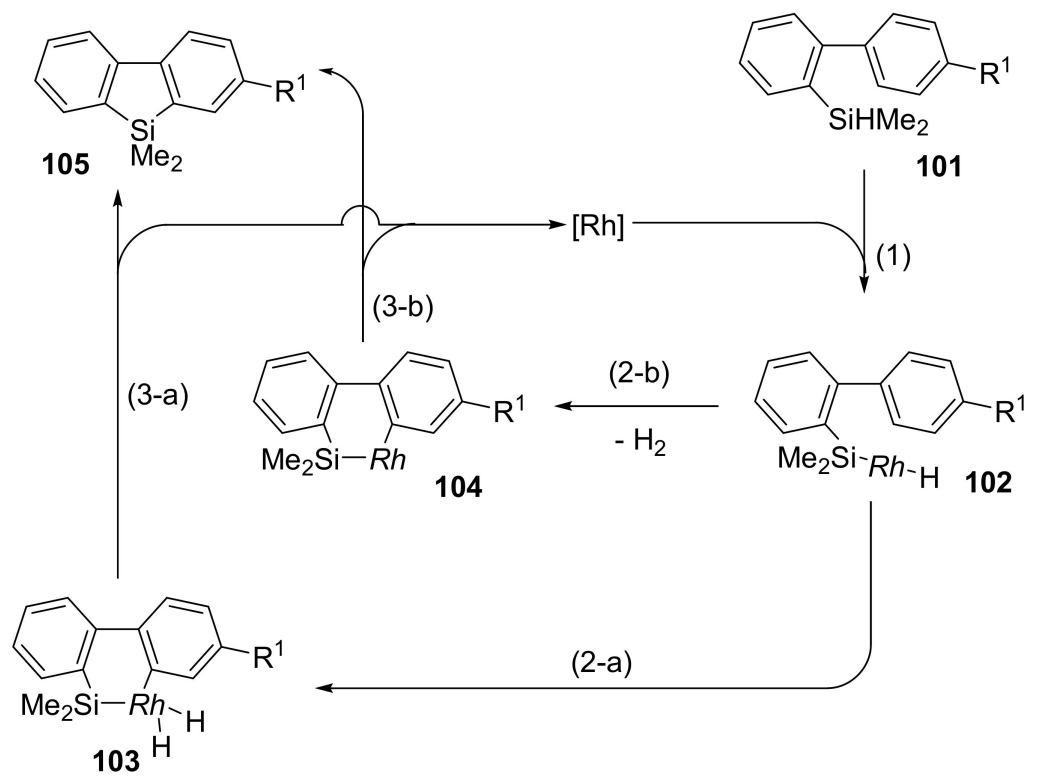

Scheme 22. Plausible mechanism for the synthesis of dibenzosilole derivatives via Rh-catalyzed C-H silylation.

In 2017, Mitsudo et al. reported a similar method to prepare $\pi$-extended benzosilolothiophenes 108 by Rh-catalyzed dehydrogenative cyclizations of isomeric silanes 106 or 107 (Scheme 23) [48]. Interestingly, a highly electron-deficient ligand $\left(\mathrm{dppe}-\mathrm{F}_{20}\right)$ was found to be the most efficient ligand in 
combination with $\left[\mathrm{Rh}(\operatorname{cod}) \mathrm{Cl}_{2}\right.$. This catalytic system was successfully and regioselectively applied for the synthesis of highly $\pi$-extended benzosilolothiophenes $\mathbf{1 1 0}$ and $\mathbf{1 1 2}$ in $92 \%$ and $75 \%$, respectively starting from 109 and 111(Scheme 24).<smiles>[R][SiH]([R])c1ccccc1-c1cccs1</smiles>

106<smiles>[R][SiH2]c1ccsc1-c1ccccc1[Te]</smiles>

107

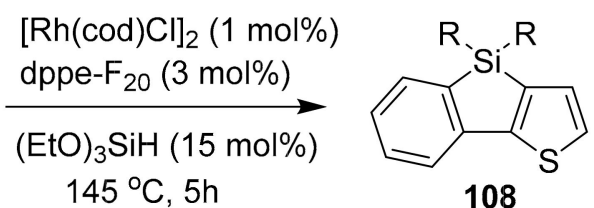

108<smiles>C[Si]1(C)c2ccccc2-c2sc3ccccc3c21</smiles>

$40 \%$<smiles>c1ccc([Si]2(c3ccccc3)c3ccccc3-c3sc4ccsc4c32)cc1</smiles>

$35 \%$<smiles>c1ccc([Si]2(c3ccccc3)c3ccccc3-c3sccc32)cc1</smiles>

$86 \%$<smiles>ClOc1cc2c(s1)-c1ccccc1[Si]2(c1ccccc1)c1ccccc1</smiles>

$55 \%$<smiles>Fc1ccc2c(c1)[Si](c1ccccc1)(c1ccccc1)c1c-2sc2ccccc12</smiles><smiles>c1ccc([Si]2(c3ccccc3)c3ccccc3-c3sc4sccc4c32)cc1</smiles>

$26 \%$<smiles>c1ccc([Si]2(c3ccccc3)c3ccccc3-c3sccc32)cc1</smiles>

$81 \%$<smiles>c1ccc([Si]2(c3ccccc3)c3ccccc3-c3sc4c(c32)CCCC4)cc1</smiles>

$96 \%$

Scheme 23. Synthesis of fused benzosilole derivatives by Rh-catalyzed C-H silylation.

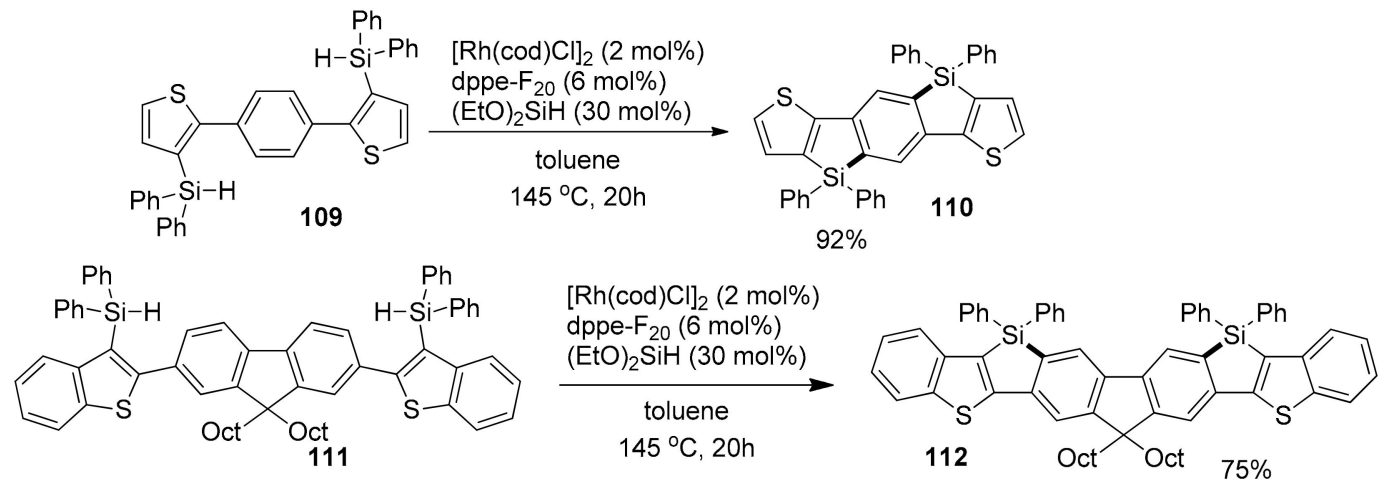

Scheme 24. Synthesis of $\pi$-extended benzosilole derivatives by two-fold Rh-catalyzed C-H silylations.

He and coworkers successfully applied this method to silane $\mathbf{1 1 3}$ for an enantioselective Rh-catalyzed synthesis of benzosilolometallocenes 114 (Fe, Ru) (Scheme 25) [49]. In the presence of $[\mathrm{Rh}(\mathrm{cod}) \mathrm{Cl}]_{2}$ catalyst and a chiral bidentate phosphine ligand ((S)-TMS-Segphos), benzosilolometallocenes $\mathbf{1 1 4}$ were prepared in very high yields with e.e. values of up to $99 \%$ under mild conditions. In the same year, Murai, Takai and Shibata groups reported very similar research describing the synthesis of benzosilolometallocenes [50,51].

Indole-fused benzosiloles exhibit promising physical properties which can be instrumental in the development of advanced luminescent materials. Therefore, the efficient synthesis of indole-fused benzosiloles derivatives from simple and inexpensive starting materials is highly important. In 2016, Omann and Oestreich reported the direct Ru-catalyzed synthesis of indole-fused benzosiloles $\mathbf{1 1 7}$ by two-fold electrophilic C-H silylation of 2-aryl indoles $\mathbf{1 1 5}$ with dihydrosilanes $\mathbf{1 1 6}$ (Scheme 26) [52]. This transformation is a challenging problem due to the intermolecular dehydrogenation coupling of indole $\mathbf{1 1 5}$ and dihydrosilane $\mathbf{1 1 6}$ being more difficult than the intramolecular dehydrogenation coupling approach. Despite having some limitations in substrate scope, this method is a highly practical 
approach to the preparation of indole-fused benzosiloles 117 using a $\mathrm{Ru}$ catalyst less expensive in comparison to other Rh-catalyzed methods.

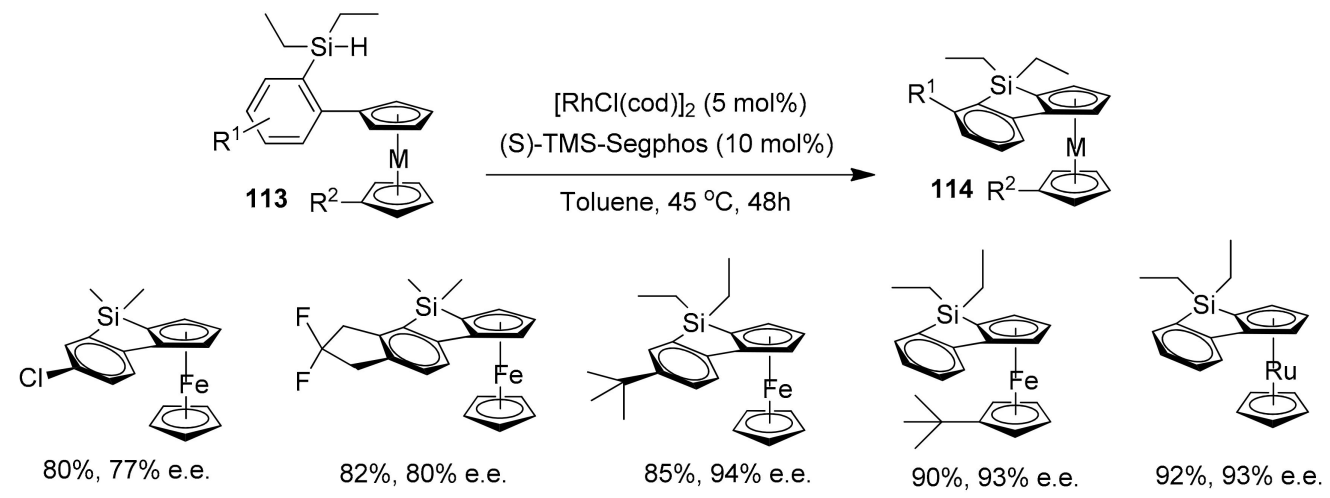

Scheme 25. Rh-catalyzed synthesis of benzosilolometallocenes via C-H silylation.
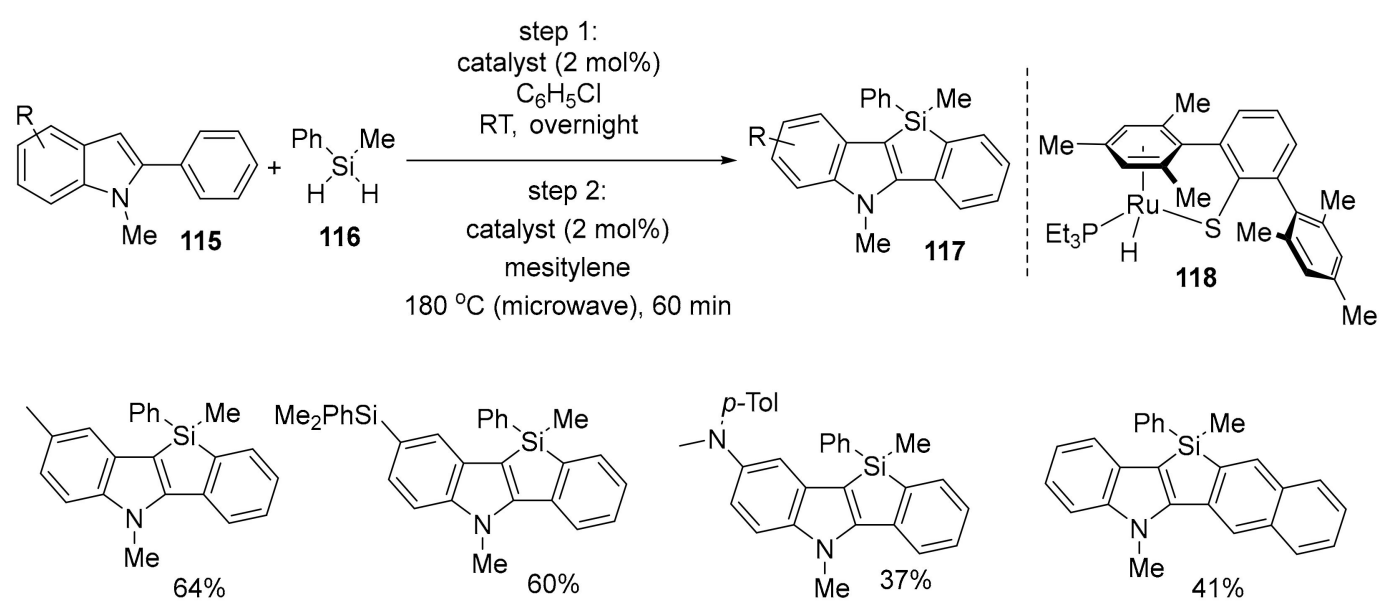

Scheme 26. Direct Ru-catalyzed synthesis of indole-fused benzosiloles using dihydrosilanes.

As mentioned above, spiro-9-silabifluorene derivatives are promising structures for their use in electronic devices. Thus far, the conventional method using BuLi induced metal exchange only gives a racemic mixture of both enantiomers in the case of R-substituted derivatives. Therefore, the development of new methods to access chiral spiro-9-silabifluorenes $\mathbf{1 2 0}$ is very important for exploring the new class of optically active silicon materials. In 2016, Takai and coworkers described an interesting Rh-catalyzed synthesis of chiral spiro-9-silabifluorenes 120 by dehydrogenative silylation of bis(biphenyl)silane 119 (Scheme 27) [53]. Chiral spiro-9-silabifluorenes 120 were successfully prepared (up to $96 \%$ yield and $95 \%$ e.e.) under mild conditions. Interestingly, some mechanistic studies were carried out to understand the construction of these tetraorganosilicon stereocenters. A similar mechanism for the synthesis of spiro-9-silabifluorenes (involving compounds 121-126) as mentioned in Scheme 28 was proposed.

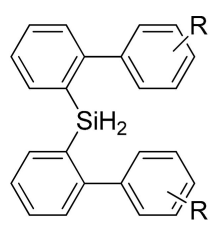

119

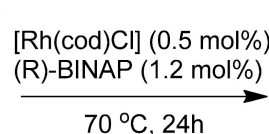

$70^{\circ} \mathrm{C}, 24 \mathrm{~h}$

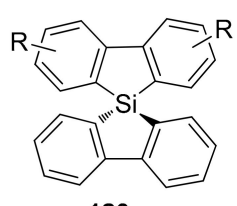

120

\begin{tabular}{|ll|}
\hline $\mathbf{R}$ & yield, e.e. (\%) \\
$4-\mathrm{MeO}$ & $96 \%, 87 \%$ \\
$4-\mathrm{CF}_{3}$ & $85 \%, 85 \%$ \\
$4-\mathrm{Ph}$ & $95 \%, 95 \%$ \\
$4-\mathrm{tBu}$ & $90 \%, 82 \%$ \\
$2-\mathrm{MeO}$ & $44 \%, 75 \%$ \\
\hline
\end{tabular}

Scheme 27. Rh-catalyzed enantioselective synthesis of chiral spiro-9-silabifluorenes. 


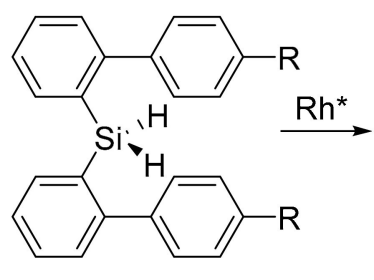

$121(\mathrm{R}=\mathrm{OMe}, \mathrm{Ph})$
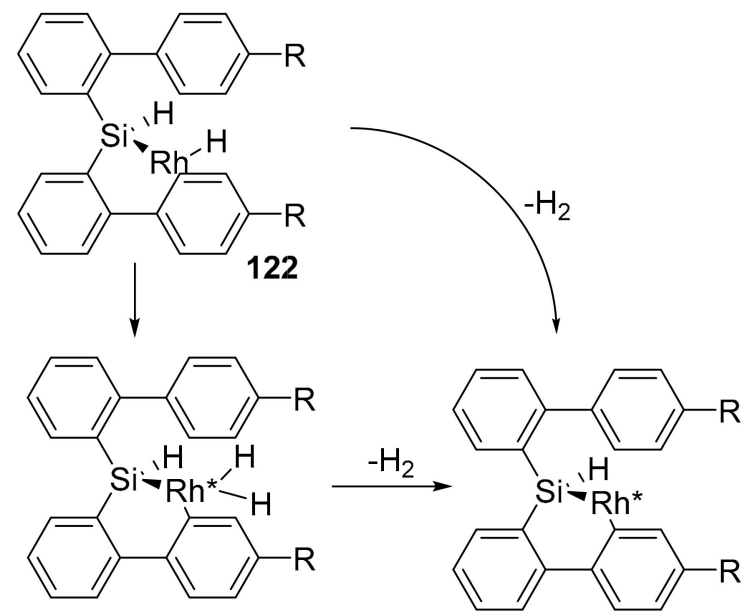

123

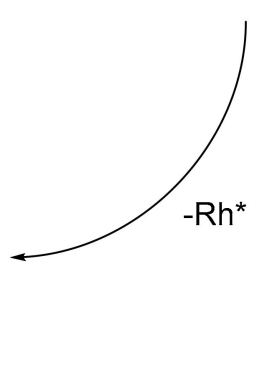

124

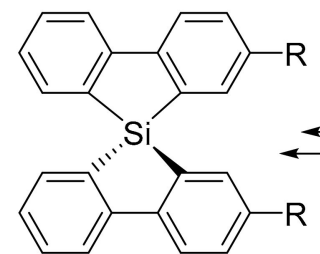

126

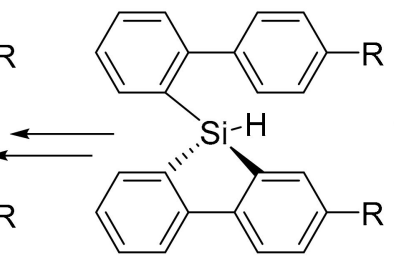

125

Scheme 28. Proposed mechanism for Rh-catalyzed synthesis of chiral spiro-9-silabifluorenes.

He and coworkers reported a new method to construct 9-silafluorene derivatives via Rh-catalyzed intramolecular $\mathrm{C}-\mathrm{H}$ silylation using silacyclobutanes $\mathbf{1 2 7}$ as key starting materials [54]. In the presence of $[\mathrm{Rh} \text { (cod)Cl }]_{2} / \mathrm{TMS}$-segphos catalyst, silacyclobutane $\mathbf{1 2 7}$ underwent sequential C-Si/C-H activations, giving the desired 9-silafluorenes 128 in very good isolated yields (Scheme 29). The proposed catalytic cycle involves a endocyclic $\beta$-hydride elimination of five-membered metallacycles, which after reductive elimination formed a Si-Rh(I) catalytic active species that is a key intermediate for the next $\mathrm{C}\left(\mathrm{sp}^{2}\right)-\mathrm{H}$ activation step (Scheme 30).<smiles>C[Si]1(c2ccccc2Br)CCC1</smiles>

127

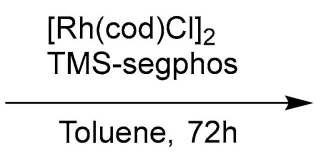

Toluene, $72 \mathrm{~h}$<smiles>[X]C1=C([Si](C)(C)C(C)C)C=CC=CC=C1</smiles>

$(\mathrm{X}=\mathrm{C}, \mathrm{S} . \mathrm{O})$
128<smiles>CC(C)[Si]1(C)c2ccccc2-c2ccccc21</smiles><smiles>CC(C)[Si]1(C)c2ccccc2-c2ccsc21</smiles>
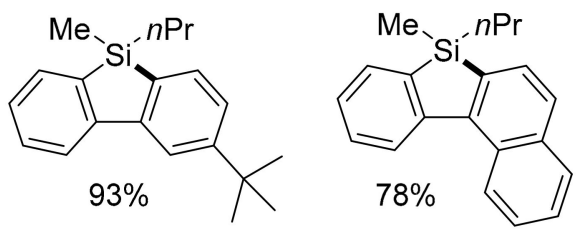<smiles>CC(C)[Si]1(C)c2ccccc2-c2cc3ccccc3cc21</smiles><smiles>CC(C)[Si]1(C(C)C)c2ccccc2-c2sc3ccccc3c21</smiles><smiles></smiles>

Scheme 29. Rh-catalyzed synthesis of 9-silabifluorenes. 


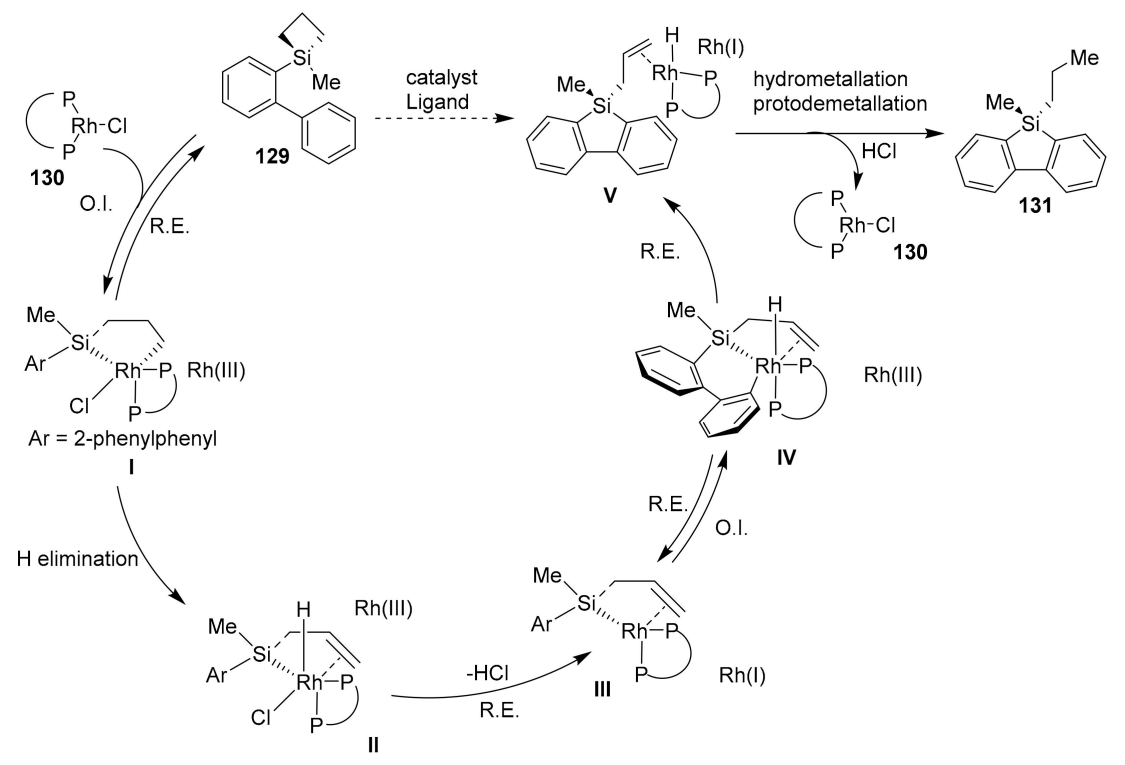

Scheme 30. Plausible mechanism for Rh-catalyzed synthesis of 9-silabifluorene.

Based on some experimental results, a plausible catalytic mechanism was proposed in Scheme 30. Firstly, a reversible oxidative insertion (O.I.) of $\mathrm{Rh}(\mathrm{I})$ catalyst $\mathbf{1 3 0}$ into silacyclobutane $\mathbf{1 2 9}$ occurred to give five-membered silametallacycle I which underwent $\beta$-H elimination to form intermediate II. The reductive elimination step of the $\mathrm{Rh}(\mathrm{III})$ complex is believed to provide $\mathrm{Rh}(\mathrm{I})$ intermediate $\mathrm{I}$ along with $\mathrm{HCl}$. Subsequently, $\mathrm{Rh}(\mathrm{III})$ intermediate IV was formed via a reversible $\mathrm{C}-\mathrm{H}$ activation. Then, the hydrometallation of terminal alkene $\mathbf{V}$ and protodemetallation with $\mathrm{HCl}$ occurred to give 9-silafluorene product 131 and regenerate the Rh catalyst 130 [54].

Relying on this research, the He group continued developing a useful method to prepare chiral dibenzosiloles 134 via tandem Rh catalyzed desymmetrization and intermolecular dehydrogenative silylations under mild conditions (Scheme 31) [55]. In fact, chiral TMS-segphos was found to be the most suitable bidentate ligand to achieve chiral products in high yields and enantioselectivity up to $93 \%$. In order to understand the mechanism of this transformation, several control experiments were carried out. The stereo-determining step is the silacyclobutane opening/intramolecular C-H silylation step of 132, giving a chiral silane intermediate $\mathbf{1 3 3}$ which reacted further with arenes.

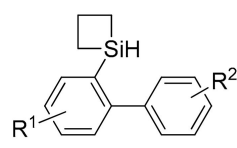

132

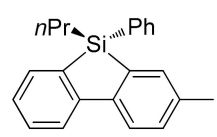

$54 \%, 65 \%$ e.e.

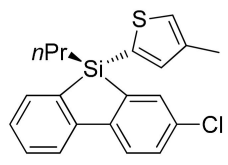

$72 \%, 92 \%$ e.e.
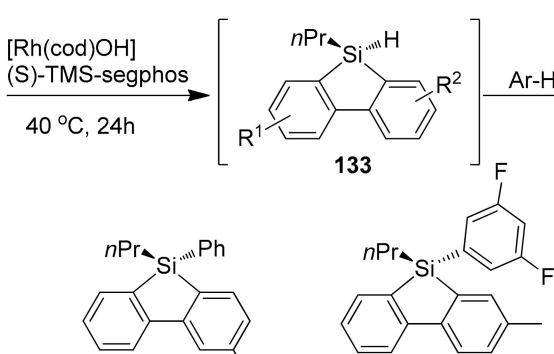

$63 \%, 67 \%$ e.e.
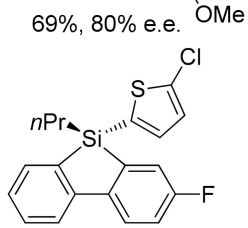

$70 \%, 91 \%$ e.e.

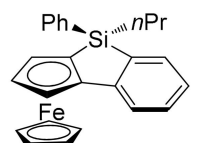

$88 \%, 91 \%$ e.e.
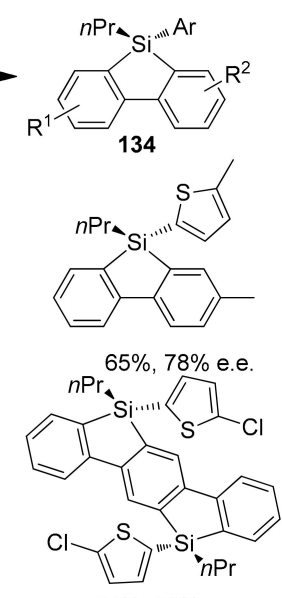

$54 \%, 92 \%$ e.e.

Scheme 31. Enantioselective Rh-catalyzed synthesis of 9-silabifluorenes. 


\subsubsection{Synthesis of Dibenzosilole Derivatives via a sila-Friedel-Crafts Reaction}

As mentioned above, the drawback of the transition metal-catalyzed $\mathrm{C}-\mathrm{H}$ silylations is the use of very expensive catalysts $(\mathrm{Rh}, \mathrm{Ru})$ and ligands. Therefore, the development of new synthetic methods leading to dibenzosiloles 138 using less expensive metals and/or cheap reagents has been receiving much attention [20]. The Friedel-Crafts reaction is a well-known method for the direct introduction of alkyl substituents into the aromatic rings. However, the sila-Friedel-Crafts reaction of $\mathbf{1 3 5}$ via silicenium ion $\mathbf{1 3 6}$ and arenium ion $\mathbf{1 3 7}$ as intermediates is quite rare and only applicable to electron rich aromatic systems such as ferrocene and pyrroles [56,57]. Remarkably, Kawashima et al. successfully applied an intramolecular sila-Friedel-Crafts reaction to the synthesis of a ladder-type silafluorene and trisilasumanene (Scheme 32). Several studies on the physical properties of these products showed a blue fluorescence in DCM and in the solid state [58].

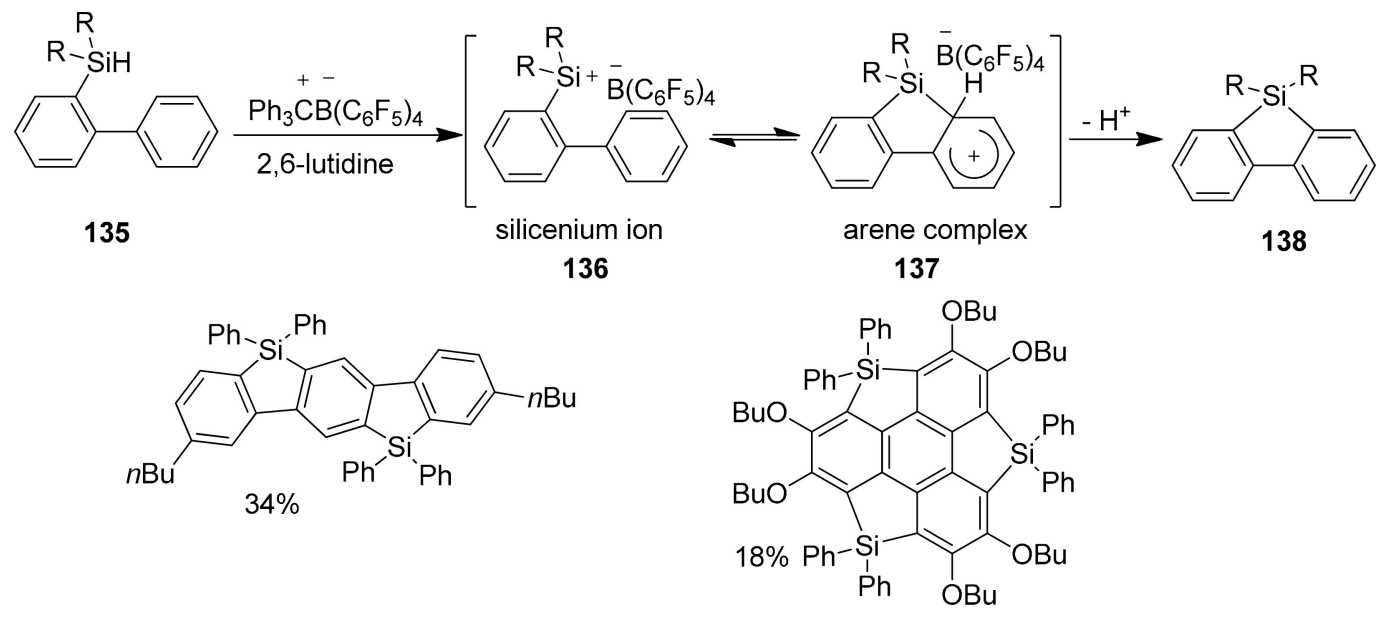

Scheme 32. Synthesis of dibenzosilole derivatives via a sila-Friedel-Crafts reaction.

The main limitations of this sila-Friedel-Crafts reaction are the requirement of a stoichiometric amount of $\mathrm{Ph}_{3} \mathrm{CB}\left(\mathrm{C}_{6} \mathrm{~F}_{5}\right)_{4}$ reagent and 2,6-lutidine base. Moreover, the yields of these reactions are low and need to be improved. Notably, Curless and Ingleson reported an efficient method using $\mathrm{B}\left(\mathrm{C}_{6} \mathrm{~F}_{5}\right)_{3}$ as catalyst to activate silanes 139 and 2,6-dimethylpyridine as base to facilitate deprotonation of the silylated arenium cation 140. A plausible catalytic cycle for the formation of 9-silafluorene 141 was proposed (Scheme 33). In addition, this method has also been successfully applied in the synthesis of benzosilole derivatives from the corresponding alkynes via a $\mathrm{Ph}_{3} \mathrm{CB}\left(\mathrm{C}_{6} \mathrm{~F}_{5}\right)_{4}$ catalyzed one-pot hydrosilylation/dehydrosilylation process [59].

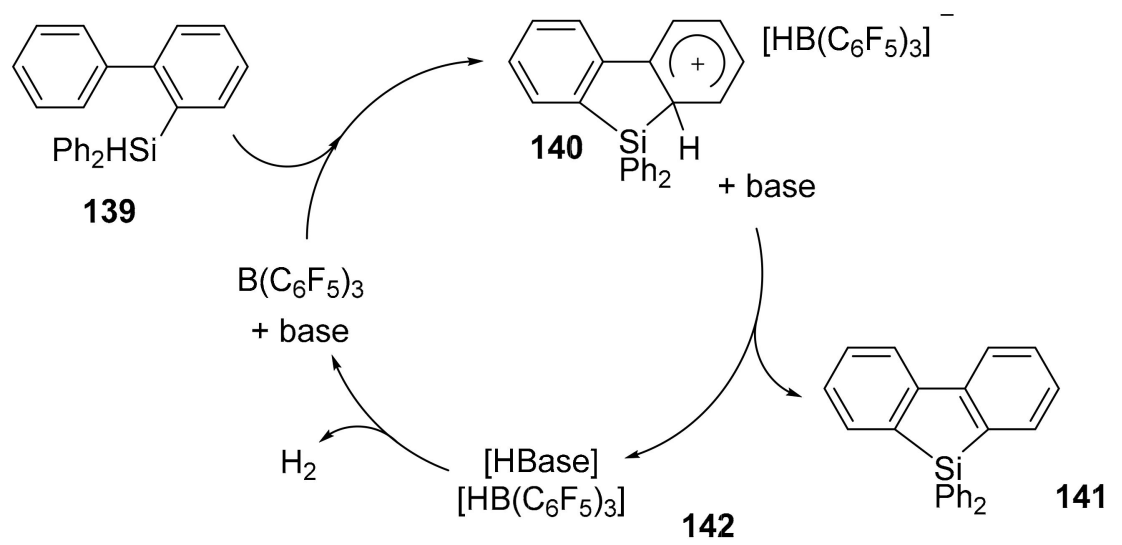

Scheme 33. Possible mechanism for the synthesis of dibenzosilole derivatives via a sila-Friedel-Crafts reaction. 


\subsubsection{Cyclizations via Silyl Radicals}

Recently, several "green" approaches have been reported to prepare benzosilole derivatives without using expensive and toxic transitions metal catalysts [60]. In 2015, Leifert and Studer disclosed a transition metal-free synthesis of 9 -silafluorenes 144 by intramolecular radical silylation of 2-diphenylsilylbiaryls 143 via base-promoted aromatic substitution (Scheme 34) [60]. The use of tert-butylhydroperoxide (TBHP) as a cheap stoichiometric oxidant in the presence of a small amount of tetrabutylammonium iodide (TBAI) is necessary for the success of this reaction. The cyclization reaction via a silyl radical process was performed under mild conditions, affording good yields of the desired products 144. A plausible mechanism for the synthesis of 9-silafluorene 149 was proposed, in which a silyl radical 146 was generated by reaction of the substrate 145 with tert-butoxyl radical as the key intermediate (Scheme 35). In this process, TBAI may act as an initiator and not as a catalyst.<smiles>[R][X]1ccc(-c2cc[R]([R])cc2)cc1</smiles><smiles>[R][R]1cccc2c1-c1cc[R1](C)cc1[Si]2(c1ccccc1)c1ccccc1</smiles><smiles>c1ccc([Si]2(c3ccccc3)c3ccccc3-c3ccccc32)cc1</smiles>

$66 \%$<smiles>CC(C)(C)c1ccc2c(c1)[Si](c1ccccc1)(c1ccccc1)c1ccccc1-2</smiles><smiles>FC(F)(F)c1ccc2c(c1)-c1ccccc1[Si]2(c1ccccc1)c1ccccc1</smiles><smiles>c1ccc([Si]2(c3ccccc3)c3ccccc3-c3ccncc32)cc1</smiles>

$39 \%$

Scheme 34. Synthesis of dibenzosilole derivatives via silyl radicals.

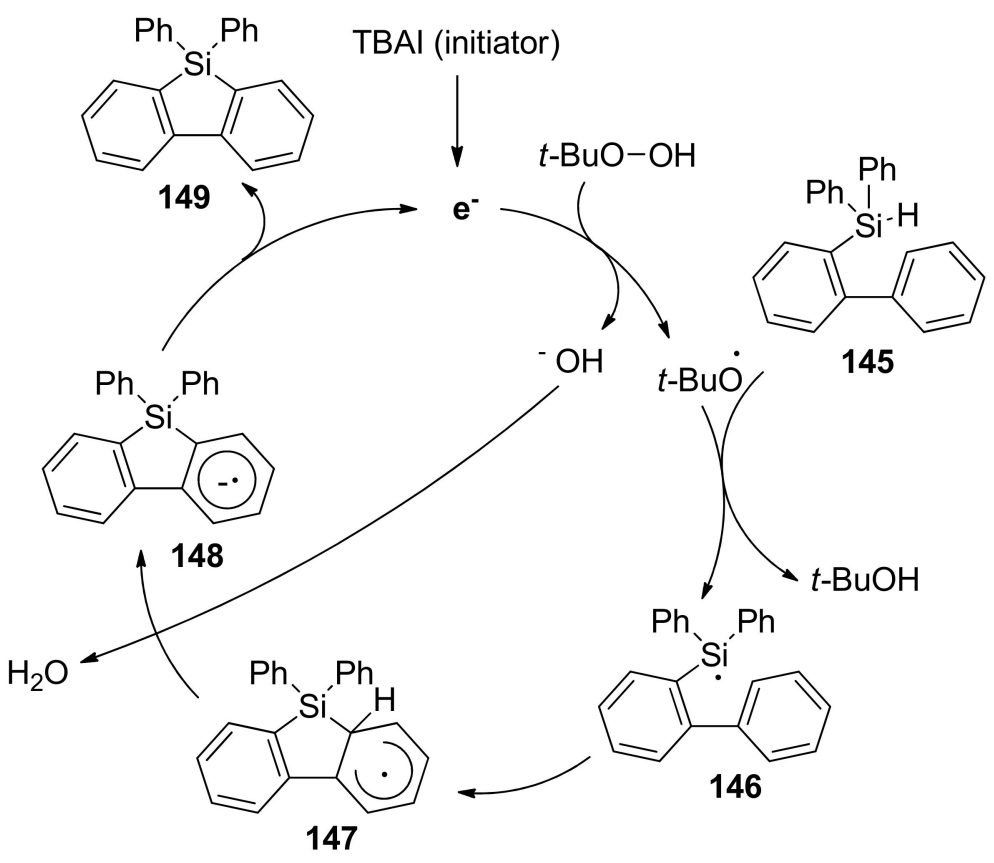

Scheme 35. Proposed mechanism for the synthesis of dibenzosilole derivatives via silyl radicals.

In 2015, Li et al. reported a similar metal-free synthesis of benzosiloles 152 and 9-silafluorenes 144 in good yields from arylhydrosilanes 150 and alkynes 151 via a silyl radical process using DTBP as the radical initiator (Scheme 36) [61]. $\mathrm{PhCF}_{3}$ was found to be the most suitable solvent for the success of 
these transformations. These catalyst-free processes may open new sustainable approaches to prepare benzosiloles, 9 -silafluorenes and $\pi$-extended benzosilole derivatives in near future.

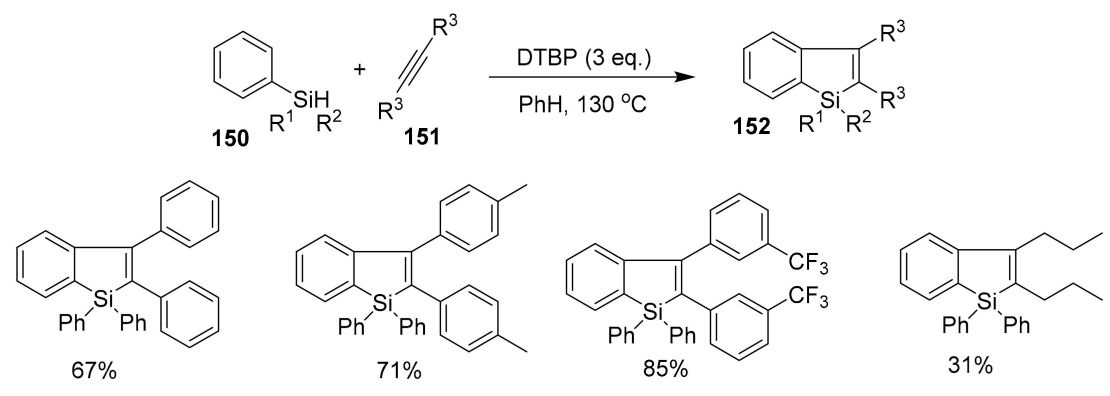

Scheme 36. Synthesis of benzosilole derivatives via silyl radicals.

Recently, visible-light photoredox catalysis has become one of the most important tools for developing new organic transformations due to its advantages such as the high tolerance to functional groups and mild operating conditions [62,63]. In 2017, Jiang et al. disclosed an efficient synthesis of dibenzosiloles 154 from biarylhydrosilanes 153 via a visible-light induced radical silylation process. In the presence of rose bengal as photocatalyst, dibenzosilole derivatives were prepared in good yields at room temperature under water/air compatible conditions (Scheme 37) [64]. Several studies on light/dark experiments and quantum yield measurements provided valuable evidences supporting the proposed photocatalytic mechanism from 155 to 159 (Scheme 38).

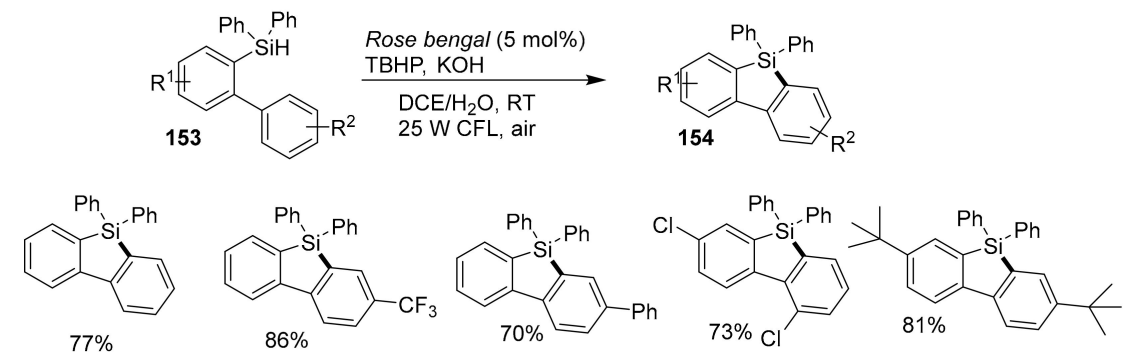

Scheme 37. Synthesis of dibenzosiloles from biarylhydrosilanes via a visible-light induced radical silylation.

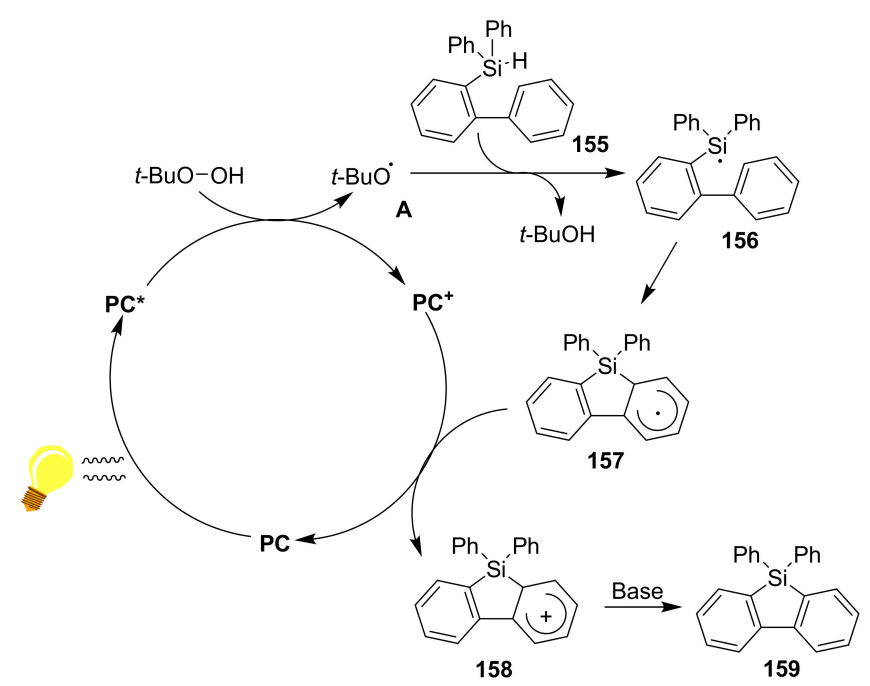

Scheme 38. Proposed mechanism for the synthesis of dibenzosiloles from biarylhydrosilanes via a visible-light induced radical silylation. 


\section{Conclusions}

In this paper, synthetic methods and important physical properties of dibenzosiloles, heterocycle-fused benzosiloles and $\pi$-extended benzosiloles have been systematically reviewed. Most of significant research in this field relies on the development of transition metal-catalyzed processes which were developed over the last decade. Several reports on transition metal-free catalytic processes also mentioned some promising results. Especially, the visible-light induced radical silylation process using catalytic amount of rose bengal sensitizer gave 9-silafluorenes in good yield at room temperature under mild condition. Up to now, many novel $\pi$-extended benzosiloles have been designed, synthesized and characterized. The fast growth of this field has opened new pathways in the development of novel advanced organic materials such as OLEDs, photovoltaic devices, and semiconductors with outstanding electronic and photophysical properties. In addition, benzosiloles, dibenzosiloles and $\pi$-extended fused benzosiloles have been successfully used as key building blocks in the design of many important polymer/copolymer materials.

Author Contributions: All authors contributed significantly to the conceptualization and realisation of the manuscript. The writing of the first draft was mainly done by T.T.D. with help for referencing and visualization from H.N. and T.N.D., revision was done by W.D. with help of the other authors. Funding to support this work was acquired by H.M.T.N., M.T.N. and W.D. All authors have read and agreed to the published version of the manuscript.

Funding: We sincerely thank the program 'Fostering innovation through Research, Science, and Technology (FIRST) of Vietnam which sponsored this work under the project number 12/FIRST/1.a/HNUE. W. D. thanks the K. U. Leuven for financial support.

Conflicts of Interest: The authors declare no competing interests.

\section{References}

1. Lu, G.; Usta, H.; Risko, C.; Wang, L.; Facchetti, A.; Ratner, M.A.; Marks, T.J. Synthesis, characterization, and transistor response of semiconducting silole polymers with substantial hole mobility and air stability. Experiment and theory. J. Am. Chem. Soc. 2008, 130, 7670-7685. [CrossRef] [PubMed]

2. Sanchez, J.C.; Urbas, S.A.; Toal, S.J.; DiPasquale, A.G.; Rheingold, A.L.; Trogler, W.C. Catalytic Hydrosilylation Routes to Divinylbenzene Bridged Silole and Silafluorene Polymers. Applications to Surface Imaging of Explosive Particulates. Macromolecules 2008, 41, 1237-1245. [CrossRef]

3. Wang, E.; Li, C.; Wenliu, Z.; Peng, J.; Cao, Y. High-efficiency red and green light-emitting polymers based on a novel wide bandgap poly(2,7-silafluorene). J. Mater. Chem. 2008, 18, 797-801. [CrossRef]

4. Shimizu, M.; Tatsumi, H.; Mochida, K.; Oda, K.; Hiyama, T. Silicon-bridge effects on photophysical properties of silafluorenes. Chem. Asian J. 2008, 3, 1238-1247. [CrossRef]

5. Chen, J.; Cao, Y. Silole-Containing Polymers: Chemistry and optoelectronic properties. Macromol. Rapid Commun. 2007, 28, 1714-1742. [CrossRef]

6. Oshita, J.; Kurushima, Y.; Lee, K.-H.; Kunai, A.; Ooyama, Y.; Harima, Y. Synthesis of bis(diarylphosphino) dithienosilole derivatives as novel photo- and electroluminescence materials. Organometallics 2007, 26, 6591-6595. [CrossRef]

7. Mouri, K.; Wakamiya, A.; Yamada, H.; Kajiwara, T.; Yamaguchi, S. Ladder Distyrylbenzenes with Silicon and Chalcogen Bridges: Synthesis, Structures, and Properties. Org. Lett. 2007, 9, 93-96. [CrossRef]

8. Li, L.; Xiang, J.; Xu, C. Synthesis of Novel Ladder Bis-Silicon-Bridged p-Terphenyls. Org. Lett. 2007, 9, 4877-4879. [CrossRef]

9. Boudreault, P.-L.T.; Michaud, A.; Leclerc, M. A New Poly(2,7-Dibenzosilole) Derivative in Polymer Solar Cells. Macromol. Rapid Commun. 2007, 28, 2176-2179. [CrossRef]

10. Sanchez, J.C.; DiPasquale, A.G.; Rheingold, A.L.; Trogler, W.C. Synthesis, luminescence properties, and explosives sensing with 1,1-tetraphenylsilole- and 1,1-silafluorene-vinylene polymers. Chem. Mater. 2007, 19, 6459-6470. [CrossRef]

11. Usta, H.; Lu, G.; Facchetti, A.; Marks, T.J. Dithienosilole- and dibenzosilole-thiophene copolymers as semiconductors for organic thin-film transistors. J. Am. Chem. Soc. 2006, 128, 9034-9035. [CrossRef] [PubMed] 
12. Wang, E.; Li, C.; Mo, Y.; Zhang, Y.; Ma, G.; Shi, W.; Peng, J.; Yang, W.; Cao, Y. Poly(3,6-silafluorene-co-2,7fluorene)-based high-efficiency and color-pure blue light-emitting polymers with extremely narrow band-width and high spectral stability. J. Mater. Chem. 2006, 16, 4133-4140. [CrossRef]

13. Lee, S.H.; Jang, B.-B.; Kafafi, Z.H. Highly Fluorescent Solid-State Asymmetric Spirosilabifluorene Derivatives. J. Am. Chem. Soc. 2005, 127, 9071-9078. [CrossRef] [PubMed]

14. Chan, K.L.; McKiernan, M.J.; Towns, C.R.; Holmes, A.B. Poly(2,7-dibenzosilole): A Blue Light Emitting Polymer. J. Am. Chem. Soc. 2005, 127, 7662-7663. [CrossRef]

15. Xu, C.; Wakamiya, A.; Yamaguchi, S. Ladder Oligo(p-phenylenevinylene)s with Silicon and Carbon Bridges. J. Am. Chem. Soc. 2005, 127, 1638-1639. [CrossRef]

16. McCulloch, I.; Ashraf, R.S.; Biniek, L.; Bronstein, H.; Combe, C.; Donaghey, J.E.; James, D.I.; Nielsen, C.B.; Schroeder, B.C.; Zhang, W. Design of Semiconducting indacenodithiophene polymers for high performance transistors and solar cells. Acc. Chem. Res. 2012, 45, 714-722. [CrossRef]

17. Chen, X.-K.; Zou, L.-Y.; Ren, A.-M.; Fan, J.-X. How dual bridging atoms tune structural and optoelectronic properties of ladder-type heterotetracenes? a theoretical study. Phys. Chem. Chem. Phys. 2011, 13, 19490-19498. [CrossRef]

18. Richter, S.C.; Oestreich, M. Emerging strategies for C-H silylation. Trends Chem. 2019, 2, 13-17. [CrossRef]

19. Cheng, C.; Hartwig, J.F. Catalytic silylation of unactivated C-H bonds. Chem. Rev. 2015, 115, 8946-8975. [CrossRef]

20. Shang, X.; Liu, Z.-Q. Recent developments in free-radical-promoted C-Si formation via selective C-H/Si-H functionalization. Org. Biomol. Chem. 2016, 14, 7829-7831. [CrossRef]

21. Dubac, J.; Laporterie, A.; Manuel, G. Group 14 metalloles. 1. Synthesis, organic chemistry, and physicochemical data. Chem. Rev. 1990, 90, 215-263. [CrossRef]

22. Hudrlik, P.F.; Dai, D.; Hudrlik, A.M. Reactions of dilithiobutadienes with monochlorosilanes: Observation of facile loss of organic groups from silicon. J. Organomet. Chem. 2006, 691, 1257-1264. [CrossRef]

23. Ishikawa, M.; Tabohashi, T.; Sugisawa, H.; Nishimura, K.; Kumada, M. Chemistry of siloles. The reactions of siloles with organolithium reagents. J. Organomet. Chem. 1983, 250, 109-119. [CrossRef]

24. Kira, M.; Sakamoto, K.; Sakurai, H. Photochemistry of dibenzo-1,1,2,2-tetramethyl-1,2-disilacyclohexa-3,5diene and the germanium analog. Exclusive extrusion of the divalent species. J. Am. Chem. Soc. 1983, 105, 7469-7470. [CrossRef]

25. Gilman, H.; Gorsich, R.D. A silicon analog of 9,9-diphenyl fluorence. J. Am. Chem. Soc. 1955, 77, 6380-6381. [CrossRef]

26. Mo, Y.; Tian, R.; Shi, W.; Cao, Y. Ultraviolet-emitting conjugated polymer poly (9,9'-alkyl-3,6-silafluorene) with a wide band gap of $4.0 \mathrm{eV}$. Chem. Commun. 2005, 4925-4926. [CrossRef]

27. Chan, K.L.; Watkins, S.E.; Mak, C.S.K.; McKiernan, M.J.; Towns, C.R.; Pascu, S.I.; Holmes, A.B. Poly(9,9-dialkyl-3,6-dibenzosilole)-a high energy gap host for phosphorescent light emitting devices. Chem. Commun. 2005, 5766-5768. [CrossRef]

28. Chen, R.-F.; Fan, Q.-L.; Zheng, C.; Huang, W. A General strategy for the facile synthesis of 2,7-dibromo-9-heterofluorenes. Org. Lett. 2006, 8, 203-205. [CrossRef]

29. Ashraf, R.S.; Chen, Z.; Leem, D.S.; Bronstein, H.; Zhang, W.; Schroeder, B.C.; Geerts, Y.; Smith, J.; Watkins, S.; Anthopoulos, T.D.; et al. Silaindacenodithiophene semiconducting polymers for efficient solar cells and high mobility ambipolar transistors. Chem. Mater. 2011, 23, 768-770. [CrossRef]

30. Wang, J.-Y.; Hau, S.K.; Yip, H.-L.; Davies, J.A.; Chen, K.-S.; Zhang, Y.; Sun, Y.; Jen, A.K.-Y. Benzobis(silolothiophene)-based low bandgap polymers for efficient polymer solar cells. Chem. Mater. 2011, 23, 765-767. [CrossRef]

31. Chen, W.; Ijadi-Maghsoodi, S.; Barton, T.J. Synthesis and study of conjugated polymers containing silole units. Polym. Prepr. 1997, 38, 189-190.

32. Baehr, S.; Ogasawara, H.; Yamaguchi, S.; Oestreich, M. An expedient produre for the synthesis of benzo[4,5]silolo[2,3-b]thiophenes and related systems. Organometallics 2017, 36, 4013-4019. [CrossRef]

33. Xu, C.; Yamada, H.; Wakamiya, A.; Yamaguchi, S.; Tamao, K. Ladder bis-silicon-bridged stilbenes as a new building unit for fluorescent $\pi$-conjugated polymers. Macromolecules 2004, 37, 8978-8983. [CrossRef]

34. Gilman, H.; Gorsich, R.D. Cyclic organosilicon compounds. I. Synthesis of compounds containing the dibenzosilole nucleus. J. Am. Chem. Soc. 1958, 80, 1883-1886. 
35. Xiao, H.; Leng, B.; Tian, H. Hole transport triphenylamine-spirosilabifluorene alternating copolymer: Synthesis and optical, electrochemical and electroluminescent properties. Polymer 2005, 46, 5707-5713. [CrossRef]

36. Van der Boon, L.J.P.; Gelderen, L.; de Groot, T.R.; Lutz, M.; Slootweg, C.J.; Ehlers, A.W.; Lammertsma, K. Chiral control in pentacoordinate systems: The case of organosilicates. Inorg. Chem. 2018, 57, 12697-12708. [CrossRef]

37. Van der Boon, L.J.P.; Hendriks, J.H.; Roolvink, D.; O’Kennedy, S.J.; Lutz, M.; Slootweg, C.J.; Ehlers, A.W.; Lammertsma, K. Dynamic conformational behavier in stable pentaorganosilicates. Eur. J. Inorg. Chem. 2019, 2019, 3318-3328. [CrossRef]

38. Matsuda, T.; Kadowaki, S.; Goya, T.; Murakami, M. Synthesis of silafluorenes by Iridium-catalyzed [2+2+2] cycloaddition of silicon-bridged diynes with alkynes. Org. Lett. 2007, 9, 133-136. [CrossRef]

39. Shibata, T.; Uchiyama, T.; Yoshinami, Y.; Takayasu, S.; Tsuchikama, K.; Endo, K. Highly enantioselective synthesis of silahelicenes using Ir-catalyzed [2+2+2] cycloaddition. Chem. Commun. 2012, 48, 1311-1313. [CrossRef]

40. Mitake, A.; Nagai, R.; Sekine, A.; Takano, H.; Sugimura, N.; Kanyiva, K.S.; Shibata, T. Consecutive HDDA and TDDA reactions of silicontethered tetraynes for the synthesis of dibenzosilole-fused polycyclic compounds and their unique reactivity. Chem. Sci. 2019, 10, 6715-6720. [CrossRef]

41. Tobisu, M.; Onoe, M.; Kita, Y.; Chatani, N. Rhodium-Ccatalyzed coupling of 2-silylphenylboronic acids with alkynes leading to benzosiloles: Catalytic cleavage of C-Si bond in trialkylsilyl groups. J. Am. Chem. Soc. 2009, 131, 7506-7507. [CrossRef] [PubMed]

42. Zhang, Q.-W.; An, K.; He, W. Rhodium-catalyzed tandem cyclization/Si-C activation reaction for the synthesis of siloles. Angew. Chem. Int. Ed. 2014, 53, 5667-5671. [CrossRef] [PubMed]

43. Liang, Y.; Zhang, S.; Xi, Z. Palladium-catalyzed synthesis of Benzosilolo[2,3-b]indoles via Cleavage of a $\mathrm{C}\left(\mathrm{sp}^{3}\right)$-Si Bond and Consequent Intramolecular C(sp²)-Si Coupling. J. Am. Chem. Soc. 2011, 133, 9204-9207. [CrossRef] [PubMed]

44. Shimizu, M.; Mochida, K.; Hiyama, T. Modular Approach to Silicon-Bridged Biaryls: Palladium-Catalyzed Intramolecular Coupling of 2-(Arylsilyl)aryl Triflates. Angew. Chem. Int. Ed. 2008, 47, 9760-9764. [CrossRef] [PubMed]

45. Masaki, S.; Kenji, M.; Tamejiro, H. Highly efficient blue fluorescence from 3,20-silylene-bridged 2-phenylindoles in the solid state. J. Phys. Chem. C. 2011, 115, 11265-11274.

46. Mochida, K.; Shimizu, M.; Hiyama, T. Palladium-catalyzed intramolecular coupling of 2-[(2-Pyrrolyl)silyl]aryl triflates through 1,2-silicon migration. J. Am. Chem. Soc. 2009, 131, 8350-8351. [CrossRef]

47. Ureshino, T.; Yoshida, T.; Kuninobu, Y.; Takai, K. Rhodium-satalyzed synthesis of silafluorene derivatives via cleavage of silicon-hydrogen and carbon-hydrogen bonds. J. Am. Chem. Soc. 2010, 132, 14324-14326. [CrossRef]

48. Mitsudo, K.; Tanaka, S.; Isobuchi, R.; Inada, T.; Mandai, H.; Korenaga, T.; Wakamiya, A.; Murata, Y.; Suga, S. Rh-catalyzed dehydrogenative cyclization leading to benzosilolothiophene derivatives via $\mathrm{Si}-\mathrm{H} / \mathrm{C}-\mathrm{H}$ bond cleavage. Org. Lett. 2017, 19, 2564-2567. [CrossRef]

49. Zhang, Q.-W.; An, K.; Liu, L.-C.; Yue, Y.; He, W. Rhodium-catalyzed enantioselective intramolecular C-H Silylation for the Syntheses of Planar-Chiral Metallocene Siloles. Angew. Chem. Int. Ed. 2015, 54, 6918-6921. [CrossRef]

50. Murai, M.; Matsumoto, K.; Takeuchi, Y.; Takai, K. Rhodium-catalyzed synthesis of benzosilolometallocenes via the dehydrogenative silylation of $\mathrm{C}\left(\mathrm{sp}^{2}\right)-\mathrm{H}$ bonds. Org. Lett. 2015, 17, 3102-3105. [CrossRef]

51. Shibata, T.; Shizuno, T.; Sasaki, T. Enantioselective Synthesis of Planar-chiral benzosiloloferrocenes by Rh-catalyzed intramolecular C-H silylation. Chem. Commun. 2015, 51, 7802-7804. [CrossRef] [PubMed]

52. Omann, L.; Oestreich, M. Catalytic Access to Indole-Fused Benzosiloles by 2-Fold Electrophilic C-H silylation with dihydrosilanes. Organometallics 2017, 36, 767-776. [CrossRef]

53. Kuninobu, Y.; Yamauchi, K.; Tamura, N.; Seiki, T.; Takai, K. Rhodium-catalyzed asymmetric synthesis of spirosilabifluorene derivatives. Angew. Chem. Int. Ed. 2013, 52, 1520-1522. [CrossRef] [PubMed]

54. Zhang, Q.-W.; An, K.; Liu, L.-C.; Guo, S.; Jiang, C.; Guo, H.; He, W. Rhodium-catalyzed intramolecular C-H silylation by silacyclobutanes. Angew. Chem. Int. Ed. 2016, 55, 6319-6323. [CrossRef] [PubMed] 
55. Zhang, Q.-W.; An, K.; Liu, L.-C.; Zhang, Q.; Guo, H.; He, W. Construction of chiral tetraorganosilicons by tandem desymmetrization of silacyclobutanes/intermolecular dehydrogenative silylation. Angew. Chem. Int. Ed. 2016, 55, 1125-1129.

56. Sollott, G.P.; Peterson, W.R. Silylation of ferrocene by chloro- and aminosilanes under Friedel-Crafts conditions. J. Am. Chem. Soc. 1967, 89, 5054-5056. [CrossRef]

57. Simchen, G.; Frick, U. elektrophile silylierung elektronenreicher heteroaromaten. Synthesis 1984, 928-929.

58. Furukawa, S.; Kobayashi, J.; Kawashima, T. Development of a sila-Friedel-Crafts reaction and its application to the synthesis of dibenzosilole derivatives. J. Am. Chem. Soc. 2009, 131, 14192-14193. [CrossRef]

59. Curless, L.D.; Ingleson, M.J. $\mathrm{B}\left(\mathrm{C}_{6} \mathrm{~F}_{5}\right)_{3}$-catalyzed synthesis of benzofused-Siloles. Organometallics 2014, 33, 7241-7246. [CrossRef]

60. Leifert, D.; Studer, A. 9-Silafluorenes via base-promoted homolytic aromatic substitution (BHAS)-The electron as a catalyst. Org. Lett. 2015, 17, 386-389. [CrossRef]

61. Xu, L.; Zhang, S.; Li, P. Synthesis of silafluorenes and silaindenes via silyl radicals from arylhydrosilanes: Intramolecular cyclization and intermolecular annulation with alkynes. Org. Chem. Front. 2015, 2, 459-463. [CrossRef]

62. Narayanam, J.M.R.; Stephenson, C.R.J. Visible light photoredox catalysis: Applications in organic synthesis. Chem. Soc. Rev. 2011, 40, 102-113. [CrossRef] [PubMed]

63. Prier, C.K.; Rankic, D.A.; MacMillan, D.W.C. Visible Light Photoredox Catalysis with Transition Metal Complexes: Applications in Organic Synthesis. Chem. Rev. 2013, 113, 5322-5363. [CrossRef] [PubMed]

64. Yang, C.; Wang, J.; Li, J.; Ma, W.; An, K.; He, W.; Jiang, C. Visible-light induced radical silylation for the synthesis of dibenzosiloles via dehydrogenative cyclization. Adv. Synth. Catal. 2018, 17, 3049-3054. [CrossRef]

(C) 2020 by the authors. Licensee MDPI, Basel, Switzerland. This article is an open access article distributed under the terms and conditions of the Creative Commons Attribution (CC BY) license (http://creativecommons.org/licenses/by/4.0/). 